University of South Florida

DIGITAL COMMONS

Digital Commons @ University of

@ UNIVERSITY OF SOUTH FLORIDA

South Florida

3-15-2001

\title{
Annual Cycle of Primary Production in the Cariaco Basin: Response to Upwelling and Implications for Vertical Export
}

Frank E. Muller-Karger

University of South Florida, carib@usf.edu

Ramon Varela

Estacion de Investigaciones Marinas de Margarita

Robert Thunell

University of South Carolina

Mary Scranton

State University of New York

Richard Bohrer

University of South Florida

See next page for additional authors

Follow this and additional works at: https://digitalcommons.usf.edu/msc_facpub

Part of the Marine Biology Commons

\section{Scholar Commons Citation}

Muller-Karger, Frank E.; Varela, Ramon; Thunell, Robert; Scranton, Mary; Bohrer, Richard; Taylor, Gordon; Capelo, Juan; Astor, Yrene; Tappa, Eric; Ho, Tung-Yuan; and Walsh, John J., "Annual Cycle of Primary Production in the Cariaco Basin: Response to Upwelling and Implications for Vertical Export" (2001). Marine Science Faculty Publications. 56.

https://digitalcommons.usf.edu/msc_facpub/56

This Article is brought to you for free and open access by the College of Marine Science at Digital Commons @ University of South Florida. It has been accepted for inclusion in Marine Science Faculty Publications by an authorized administrator of Digital Commons @ University of South Florida. For more information, please contact digitalcommons@usf.edu. 


\section{Authors}

Frank E. Muller-Karger, Ramon Varela, Robert Thunell, Mary Scranton, Richard Bohrer, Gordon Taylor, Juan Capelo, Yrene Astor, Eric Tappa, Tung-Yuan Ho, and John J. Walsh 


\title{
Annual cycle of primary production in the Cariaco Basin: Response to upwelling and implications for vertical export
}

\author{
Frank Muller-Karger, ${ }^{1}$ Ramon Varela, ${ }^{2}$ Robert Thunell, ${ }^{3}$ Mary Scranton, ${ }^{4}$ \\ Richard Bohrer, ${ }^{1}$ Gordon Taylor, ${ }^{4}$ Juan Capelo, ${ }^{2}$ Yrene Astor, ${ }^{2}$ \\ Eric Tappa, ${ }^{3}$ Tung-Yuan Ho, ${ }^{4}$ and John J. Walsh ${ }^{1}$
}

\begin{abstract}
Monthly hydrographic, primary production, bacterial production, and settling particulate carbon flux observations were collected between November 1995 and December 1997 at $10.5^{\circ} \mathrm{N}, 64.67^{\circ} \mathrm{W}$ within the Cariaco Basin, off Venezuela. Upwelling of Subtropical Underwater (SUW) started around October and lasted through approximately May of the following year. Wind speeds $>7 \mathrm{~m} \mathrm{~s}^{-1}$ were observed between January and June, with weaker winds $\left(<5 \mathrm{~m} \mathrm{~s}^{-1}\right)$ between July and December. The upwelling cycle was therefore out of phase with that of the trade winds by 2-3 months. A seasonal cycle punctuated by transient extremes associated with subsurface ventilation events was observed in primary production. High bacterial activity and organic carbon recycling rates were observed near the oxic-anoxic interface. Integrated primary production was $690 \mathrm{gC}$ $\mathrm{m}^{-2} \mathrm{yr}^{-1}$ in 1996 and $540 \mathrm{gC} \mathrm{m}^{-2} \mathrm{yr}^{-1}$ in 1997. Settling carbon flux measured with sediment traps was about $5.6 \%$ of integrated primary production at $275 \mathrm{~m}$ and about $1.7 \%$ at $1225 \mathrm{~m}$, with no seasonality in the proportion of vertical flux to primary production. In total, between 10 and $11 \mathrm{gC} \mathrm{m}^{-2} \mathrm{yr}^{-1}$ were delivered to the bottom sediment of Cariaco, which suggests that between $4 \times 10^{5}$ and $1 \times 10^{6} \mathrm{t} \mathrm{C} \mathrm{yr}^{-1}$ were delivered to sediments within the upwelling area of the Cariaco Basin. This represents permanent sequestration of carbon previously entrained in the North Atlantic gyre in the area of formation of SUW. Results suggests that upwelled inorganic nitrogen, rather than nitrogen fixation, is responsible for the large productivity and particulate carbon settling flux in the Cariaco Basin.
\end{abstract}

\section{Introduction}

Over geological timescales, geochemical imbalances at the Earth's surface are closely tied to carbon sequestration by marine organisms and to the sinking flux of particulate organic material [Berner, 1992]. This variable flux serves as a key to interpreting past climate when preserved at depth. However, the relationship between fossil flux and oceanographic conditions near the ocean's surface must be analyzed to understand how these records can be used to make inferences about climate change. There are few places where flux observations have been linked to climatic and oceanographic forcing conditions [Deuser et al., 1990; Karl et al., 1996; Thunell, 1998a]. Indeed, only in a few locations do the underlying sediments preserve variability spanning a wide range of timescales. This has made it difficult to establish the relationship between productivity in surface waters and biogeochemical feedbacks acting over decadal and century timescales [see Falkowski et al., 1998].

\footnotetext{
${ }^{1}$ College of Marine Science, University of South Florida, St. Petersburg, Florida.

${ }^{2}$ Fundacion La Salle de Ciencias Naturales, Estacion de Investigaciones Marinas de Margarita, Isla de Margarita, Venezuela.

${ }^{3}$ Department of Geological Sciences, University of South Carolina, Columbia, South Carolina.

${ }^{4}$ Marine Sciences Research Center, State University of New York, Stony Brook, New York.

Copyright 2001 by the American Geophysical Union.

Paper number 1999JC000291.

0148-0227/01/1999JC000291\$09.00
}

Many studies have focused on the present balance between inorganic and organic pools in the deep ocean [see, e.g., Hansell and Carlson, 1998, and references therein], but the contribution toward this balance by waters near continental margins remains unclear. All attempts at global assessments of marine primary production indicate that ocean margins support on the average 2-5 times the annual production of open ocean waters [Koblentz-Mishke et al., 1970; Field et al., 1998]. Indeed, the mean particle flux at $2300 \mathrm{~m}$ along continental margins is of the order of about $7.0 \mathrm{gC} \mathrm{m}^{-2} \mathrm{yr}^{-1}$, compared to $\sim 0.8 \mathrm{gC} \mathrm{m}^{-2}$ $\mathrm{yr}^{-1}$ at $2300 \mathrm{~m}$ in the deep sea [Deuser et al., 1990; Walsh, 1991; Pilskaln et al., 1996; Thunell, 1998b]. Globally, over $65 \%$ of the particulate carbon that falls below $1000 \mathrm{~m}$ is derived from the slope and rise of continental margins [Jahnke, 1996], and this estimate does not include areas shallower than $1000 \mathrm{~m}$ [see also Honjo et al., 1982; Spencer, 1984; Walsh et al., 1992]. These simple statistics suggest that the biological pump [Volk and Liu, 1988] is much more efficient in the vicinity of continental margins than in the ocean's interior.

To try to understand the connection between surface production and vertical carbon flux in a productive setting, we started a series of monthly hydrographic and productivity observations and deployed a set of sediment traps in the Cariaco Basin, off the coast of Venezuela. These observations form the basis of the Carbon Retention in a Colored Ocean (CARIACO) study. Here we discuss the first 2 years of observations at the CARIACO site.

The Cariaco Basin (Figure 1) offers a unique geographical setting that permits studies that are difficult or impossible to conduct at other sites. This is a large $(\sim 160 \mathrm{~km}$ long, $70 \mathrm{~km}$ 


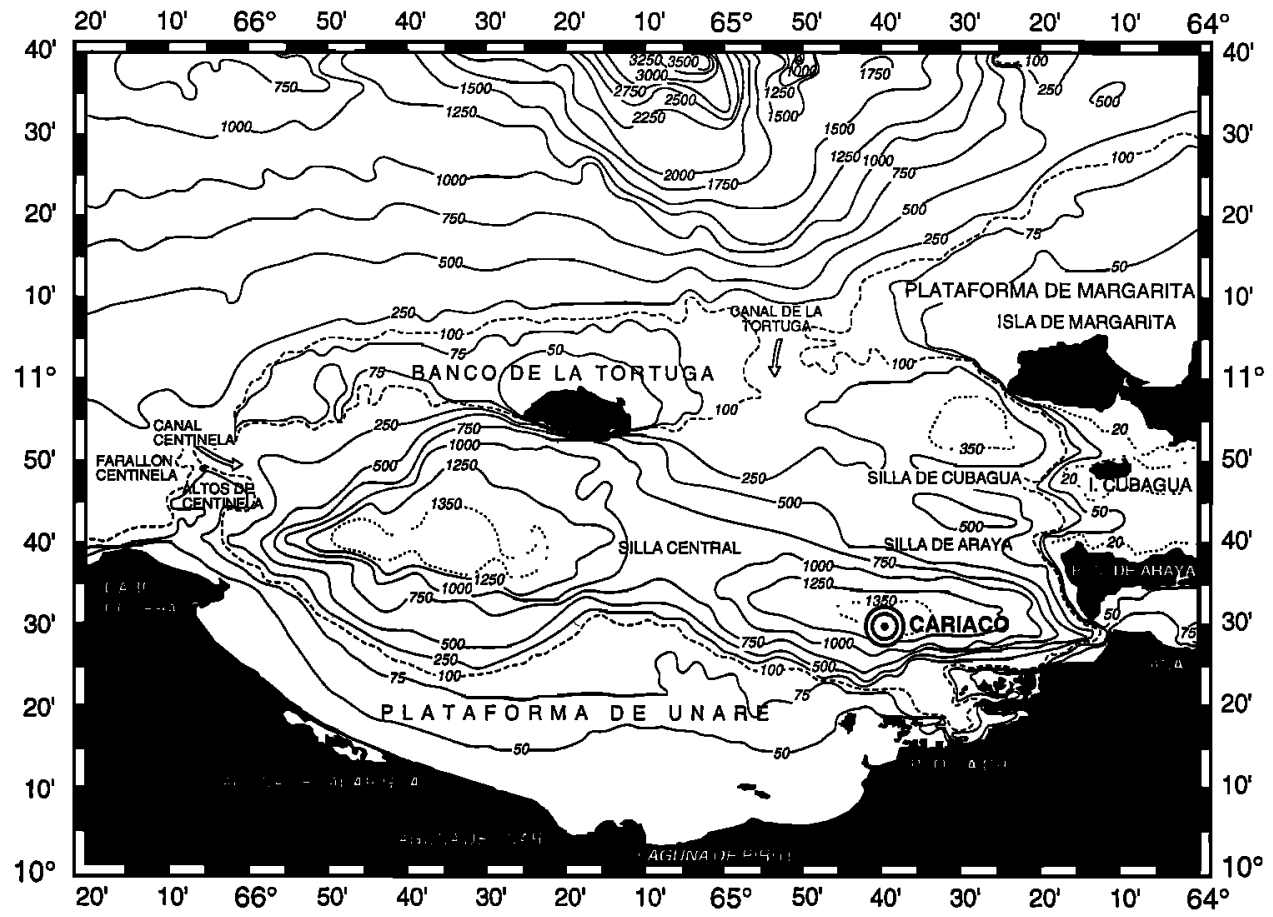

Figure 1. The Cariaco Basin: bathymetry and location of the CARIACO time series station [modified from Febres-Ortega and Herrera, 1975].

wide) and deep ( $\sim 1400 \mathrm{~m})$ basin within a continental shelf. It is bound to the north by a sill connecting Margarita Island to Cabo Codera at a mean depth of about $100 \mathrm{~m}$. There are two channels breaching this sill (Figure 1): one in the northeast of $135 \mathrm{~m}$ depth (La Tortuga) and a narrower one in the northwest of $146 \mathrm{~m}$ depth (Centinela) [Richards, 1975; Lidz et al., 1969].

Current conceptual models attribute a marked cycle in upwelling and associated sea surface temperature (SST) changes in this region primarily to the seasonal intensification of the trades along an east-west coastline [Richards, 1960, 1975; Herrera and Febres-Ortega, 1975; Muller-Karger and Aparicio, 1994]. Similar and concurrent variations in upwelling occur along the entire south/central Caribbean Sea, but we show here that winds lag behind the onset of upwelling by up to 3 months. Within the Cariaco Basin the seasonal upwelling process provides a source of nutrients that leads to vigorous phytoplankton growth near the surface. Previous studies suggest that much of this remains ungrazed and sinks, allowing pigments to reach the sediment [Richards, 1975; Richards and Vaccaro, 1956].

In contrast to the situation at other continental margins, the Cariaco Basin has a muted advective regime at depth. The sill restricts water motion and the lateral flux of material, thus forming a natural sediment trap within a continental shelf. As the turnover of basin waters is slow [Deuser, 1973], the decomposition of the sinking material leads to permanent anoxia below about $275 \mathrm{~m}$ depth. The Cariaco Basin is well known to be the largest anoxic basin of truly oceanic character. Indeed, the hydrography, chemistry, and sediment deposition processes in the Cariaco Basin are sensitive to changes in climate [e.g., Holmen and Rooth, 1990; Scranton, 1988; Scranton et al., 1987; Deuser, 1973]. Varved sediments that accumulate within the bottom anoxic waters provide a detailed record of annual- to decadal-scale change [Peterson et al., 1991; Hughen et al., 1996, 1998; Haug et al., 1998; Black et al., 1999]. The evidence suggests that even weak disturbances with a muted expression in the deep ocean are recorded temporarily within the water column in Cariaco and permanently in the sediments at the bottom of the basin.

In addition to the recent importance of the Cariaco Basin as the site of an important paleo-oceanographic time series, the Cariaco Basin has served as a natural laboratory for biogeochemists for over 40 years. This basin has been key in constructing stoichiometric models of organic matter remineralization [Redfield et al., 1963; Richards, 1975], developing residence time and box models, studying metallic sulfides $[\mathrm{Ba}$ con et al., 1980], and numerous other studies. However, very little is known about the variability in primary production or about the actual processes that control the carbon and nutrient fluxes within the basin.

\section{Methods}

Twenty-six CARIACO cruises were conducted between November 1995 and December 1997 to examine the hydrography, primary productivity, and vertical flux of material at $10.5^{\circ} \mathrm{N}$, $64.67^{\circ} \mathrm{W}$. Figure 2 is a schematic of the CARIACO logistics. The base of operations is the Estacion de Investigaciones Marinas Isla Margarita (EDIMAR) of the Fundacion La Salle de Ciencias Naturales (FLASA), located on Punta de Piedras, Margarita Island, Venezuela, and cruises use the R/V Hermano Gines (FLASA).

Wind data were collected at Santiago Mariño Airport $\left(10.9^{\circ} \mathrm{N} 63.96^{\circ} \mathrm{W}\right)$. Hourly records were averaged to daily values, and a five-point running mean was applied to generate the figures shown in this paper. Historical wind records from Punta de Piedras, Margarita Island $\left(10.9^{\circ} \mathrm{N}, 64.2^{\circ} \mathrm{W}\right)$ were also exam- 


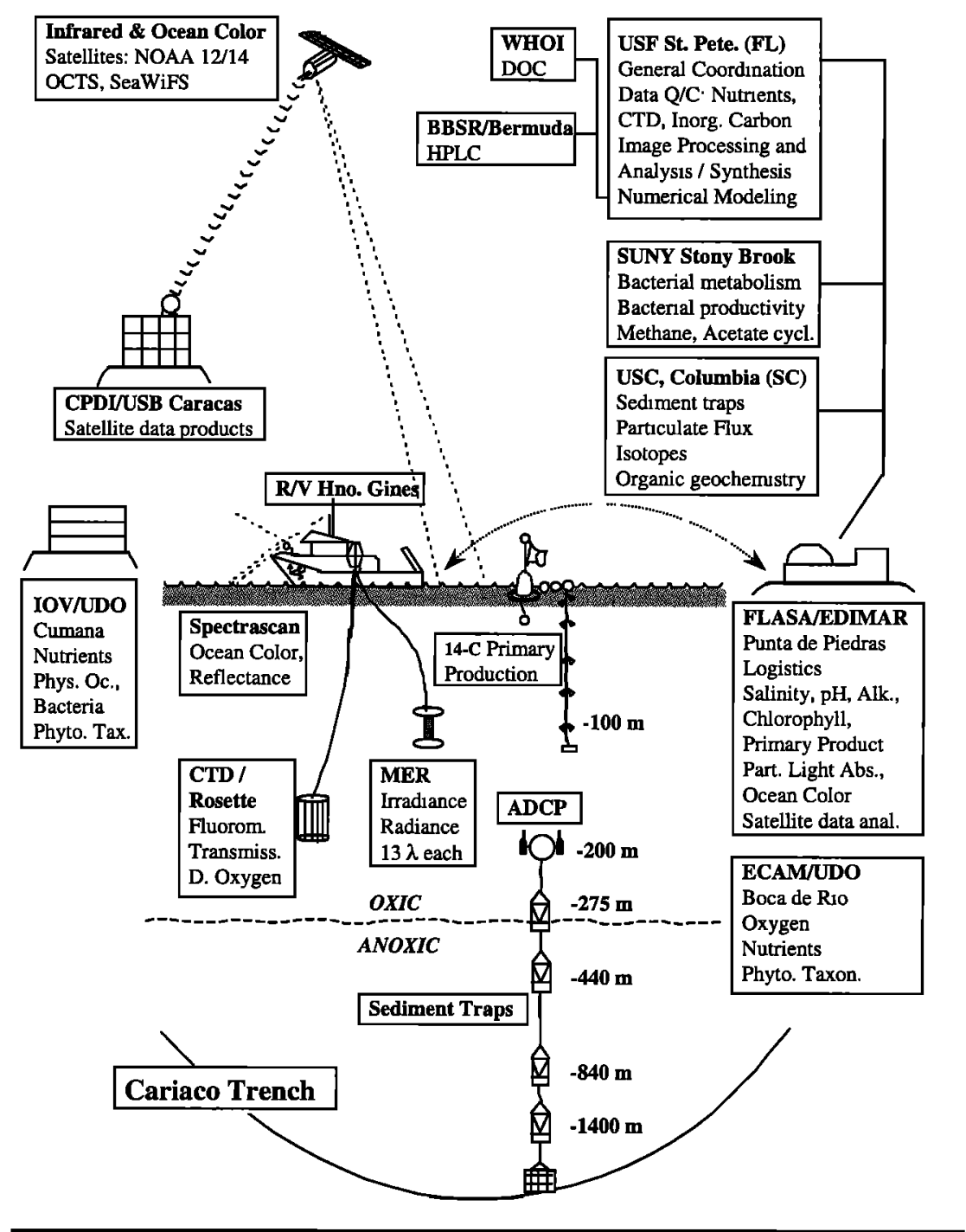

Figure 2. Schematic of the CARIACO program showing institutions involved and a summary of observations collected.

ined to assess the quality of observations at Santiago Mariño Airport.

SST was estimated in situ at $1 \mathrm{~m}$ depth with our conductivitytemperature-depth (CTD) sensors and more frequently from imagery collected by the advanced very high resolution radiometer (AVHRR) sensors on the NOAA 11, 12, and 14 satellites. The satellite SST were derived using the split window techniques [Walton, 1988; Strong and McClain, 1984; McClain et al., 1983]. While nonlinear algorithms developed for AVHRR data could be used, there is no conclusive evidence that these algorithms are any better than the multichannel sea surface temperature algorithms. The nominal accuracy of AVHRR SST retrievals is in the range of $\pm 0.3- \pm 1.0 \mathrm{~K}$ [see also Brown et al., 1985; Minnett, 1991]. In Figure 3 we show a smoothed representation of the satellite-derived SST (100point running mean) and the monthly $1 \mathrm{~m}$ CTD temperatures at CARIACO.

A minimum of five hydrocasts were performed during each monthly cruise to collect a suite of core observations. Additional hydrocasts were performed for specific process studies. Water was collected with a SeaBird ${ }^{\mathrm{TM}}$ rosette equipped with 12
(8 L) teflon-coated Niskin bottles with teflon-coated springs. The rosette housed the CTD, YSI oxygen probe, and Chelsea Instruments profiling fluorometer outfitted for chlorophyll $a$ estimates. A SeaTec c beam transmissometer (660 nm) was added to the system on the eleventh month of the time series.

For the first 10 CARIACO cruises we used a series of SeaBird SBE-19 CTDs, but we had some difficulty with inconsistent and obviously erroneous salinity data below the oxicanoxic interface with these devices. Through repetitive attempts, good profiles were obtained for each cruise. However, the SBE-19 was permanently replaced with an SBE-25 in September 1996. In addition to annual calibration by the manufacturer, each salinity profile was corrected with discrete salinity observations collected at 20 depths. The salinity measurements were conducted onshore on a Guildline ${ }^{\mathrm{TM}}$ Portasal 8410 salinometer calibrated with International Association for Physical Sciences of the Oceans (IAPSO) Standard Ocean Water.

Phytoplankton biomass was estimated with chlorophyll $a$ extracted in methanol and read on a Turner Designs fluorometer using standard methods [Holm-Hansen et al., 1965; Falkowski and Kiefer, 1985]. During the high production season 

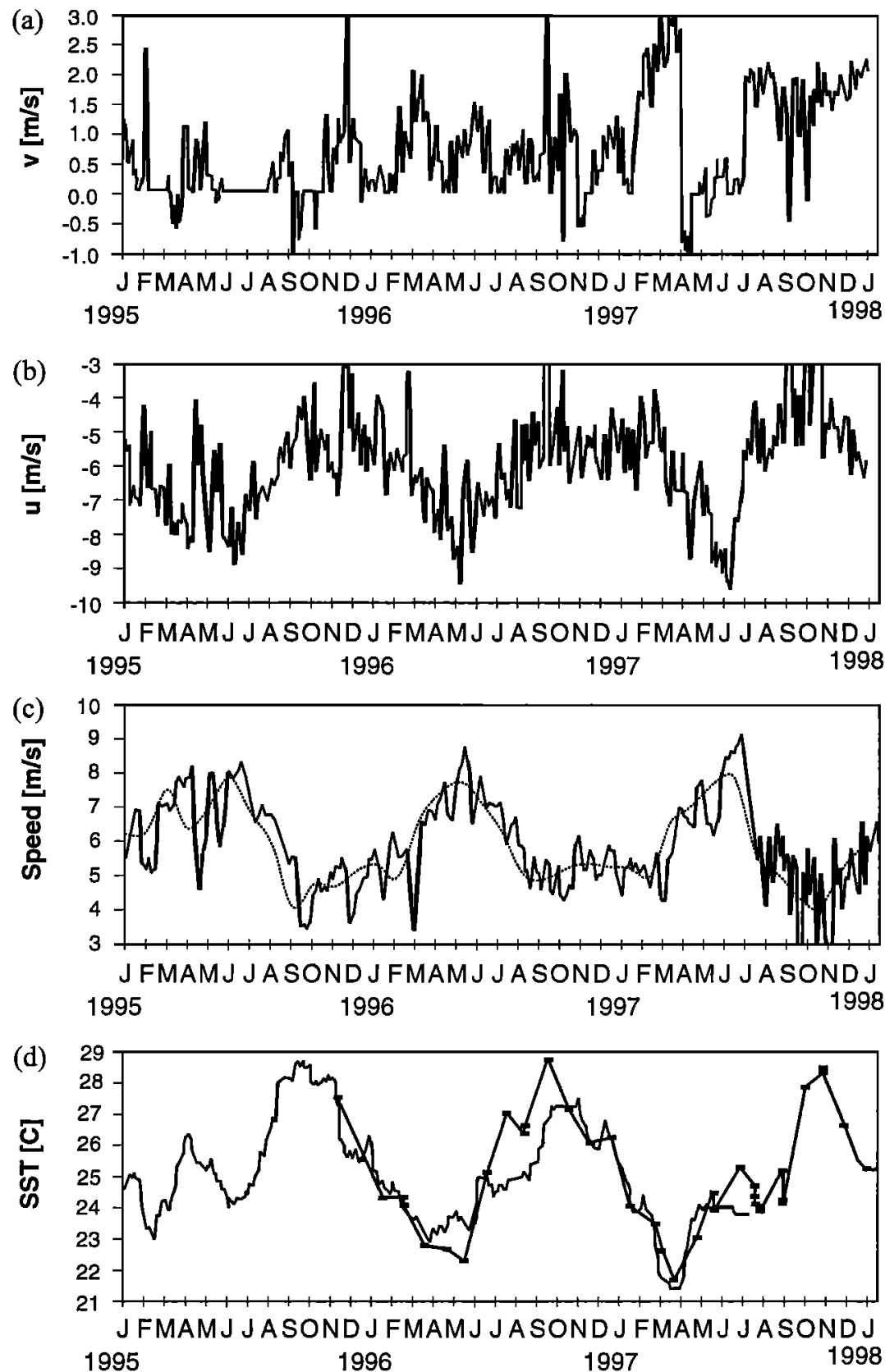

Figure 3. Wind ((a) $v$, (b) $u$, and (c) scalar speed $\left(\mathrm{m} \mathrm{s}^{-1}\right)$ ) at Santiago Mariño Airport (Margarita Island). Broken line laid over the scalar wind represents the monthly mean scalar wind. Negative $u$ and $v$ values represent westward and southward winds, respectively. (d) AVHRR-SST in a $12 \times 12 \mathrm{~km}^{2}$ area centered at the Cariaco site. Heavy line (squares) overlay represents CARIACO (in situ) temperature at 1-7 $\mathrm{m}$ depth.

(approximately January-May) $250 \mathrm{~mL}$ seawater were filtered onto $25 \mathrm{~mm}$ glass fiber filters (GF/F) filters, while $500 \mathrm{~mL}$ were filtered during the rest of the year. Three replicates were taken per depth except where biomass was clearly at its minimum, when only two were collected. Methanol extractions permitted direct comparison of concentrations estimated separately using the Kishino et al. [1985] method for measuring the light absorption coefficient by particulate matter.

Suspended particulate organic carbon (POC) was estimated by filtering water samples of known volume (generally $2 \mathrm{~L}$ ) onto precombusted GF/F. The filters were folded inside cleaned tin disks and combusted in a PE2400 Elemental An- alyzer. Cystine standard was used for calibration, and blank filters were used to determine background counts.

Primary productivity observations were made using a modified Steeman Nielsen (1952) $\mathrm{NaH}^{14} \mathrm{CO}_{3}$ uptake assay. One hour before sunrise, water from $1,7,15,25,35,55,75$, and $100 \mathrm{~m}$ was obtained. Water was poured directly from the Niskin bottle under low-light conditions into $250 \mathrm{~mL}$ clear polycarbonate bottles, which had been acid-washed, rinsed, and soaked in deionized water for over 48 hours. Bottles were rinsed three times before filling using a near-total fill. Four clear polycarbonate bottles were filled from each depth. One inoculated bottle from each depth was wrapped in aluminum 
foil to obtain the dark ${ }^{14} \mathrm{C}$ uptake rates. An extra bottle for 1 , 15,35 , and $75 \mathrm{~m}$ was filled but not inoculated to provide time zero $\left(t_{0}\right)$ filter and seawater blanks. The $t_{0}$ samples were kept in the dark in the laboratory and were filtered after deploying the floating incubation buoy.

Each sample was inoculated under low-light conditions with $1.0 \mathrm{~mL}(4 \mu \mathrm{Ci})$ of the ${ }^{14} \mathrm{C}$ sodium bicarbonate working solution. A $200 \mu \mathrm{L}$ aliquot for counting total added ${ }^{14} \mathrm{C}$ activity was removed from one of the three bottles from each depth and placed in a $20 \mathrm{~mL}$ glass scintillation vial containing $250 \mu \mathrm{L}$ ethanolamine and $10 \mathrm{~mL}$ of liquid scintillation cocktail (CytoScint ${ }^{\mathrm{TM}}$ ). The mixture was held at $5^{\circ} \mathrm{C}$ until subsequent liquid scintillation analysis onshore. A $50 \mu \mathrm{L}$ aliquot of the ${ }^{14} \mathrm{C}$ working solution in a vial with ethanolamine $(250 \mu \mathrm{L})$ and scintillation cocktail was counted for reference.

A Licor photosynthetically active radiation (PAR) integrator was used to estimate photoperiod length. Between December 1995 and November 1996, samples were incubated from 0600 to 1000 LT. Starting December 1996, the protocol was changed to incubate between 0700 and $1100 \mathrm{LT}$, which more accurately represents one third of the daily photoperiod and one third of the total energy received in 1 day at $10^{\circ} 30^{\prime} \mathrm{N}$, as verified with a Licor PAR light sensor. Incubation times were relatively short because of the potentially high productivity $\left(>1000 \mathrm{mg} \mathrm{m}^{-2}\right.$ $\mathrm{d}^{-1}$ ) of this continental margin. Upon completion of the incubations, sample bottles were removed from the mooring and placed in labeled dark plastic bags. A $50 \mathrm{~mL}$ aliquot was withdrawn from each productivity bottle and was filtered onto a 25 $\mathrm{mm}$ Whatman GF/F, which was rinsed with $0.25 \mathrm{~mL} 0.5 \mathrm{~N} \mathrm{HCl}$, placed in a $20 \mathrm{~mL}$ glass scintillation vial, sealed, and held at $5^{\circ} \mathrm{C}$ until subsequent processing onshore. Immediately upon return to the shore lab and within 15 hours of sample collection, 10 $\mathrm{mL}$ of liquid scintillation cocktail were added to vials with filters. The vials were refrigerated until analysis at Empresas Polar in Caracas, Venezuela.

Carbon uptake calculations followed the standard formulation outlined in the Joint Global Ocean Flux Study (JGOFS) manual [United Nations Educational, Scientific, and Cultural Organization (UNESCO), 1994], taking into consideration a (very low) quenching curve. To obtain the daily productivity rate, a photoperiod scaling factor that varied between 1.89 and 3.90 , according to the fraction of the energy received during the incubation period relative to the total energy received in a day, was used. This was determined by the shipboard PAR photometer. Depth-integrated and annual production estimates were derived by trapezoidal integration over the upper $100 \mathrm{~m}$ and then across months.

Total dissolved inorganic carbon $\left(\mathrm{TCO}_{2}\right.$, hereinafter here referred to as DIC) was calculated from measurements of total alkalinity and of $\mathrm{pH}$ on the total hydrogen ion concentration scale at $25^{\circ} \mathrm{C}$. These estimates are performed using the precise spectrophotometric dye methods developed by Robert-Baldo et al. [1985] and Byrne and Breland [1989] and modified from Clayton and Byrne [1993] and Breland and Byrne [1993]. A single-beam spectrophotometer (Ocean Optics) was used. The $\mathrm{pH}$ was calculated using the original equations plus an additive factor of 0.0047 , which results from a correction to the buffers used in the original paper [DelValls and Dickson, 1998]. These methods circumvent the problem that arises when potentiometric electrodes are transferred from dilute buffers to seawater samples because of the sample's high ionic strength. Total DIC was calculated using the $\mathrm{K} 1$ and $\mathrm{K} 2$ equilibrium constants from Mehrbach et al. [1973]. Values for the other equilibrium constants were taken from the review of Millero [1995].

On 11 cruises, total bacterial production was measured using a modification of the method of Kirchman [1993]. Discrete samples from 12 to 18 depths were transferred (in triplicate), under a nitrogen atmosphere, to $40 \mathrm{~mL}$ vials with Teflon-lined butyl rubber septa. Each vial was allowed to overflow two to three vial volumes and was sealed without headspace to maintain ambient redox conditions. Hydrogen 3-leucine (10 nM final concentration) was introduced into each vial via syringe. Samples were incubated in the dark for 8-10 hours in water baths maintained at in situ temperatures. Incubations were terminated by transferring the contents of an entire vial to tubes containing trichloroacetic acid (5\% final concentration), which lysed cells and precipitated macromolecules. Acidified and chilled samples were processed as described by Kirchman [1993] upon return to EDIMAR. Bacterial production was estimated by measuring ${ }^{3} \mathrm{H}$-leucine incorporation into precipitated protein after subtracting activity of control samples sacrificed immediately after isotope addition to correct for abiotic processes. Carbon production was derived by assuming constant proportions of leucine and protein in bacterial biomass [Kirchman, 1993]. Bacterial production on an areal basis (mg C $\mathrm{m}^{-2} \mathrm{~d}^{-1}$ ) was calculated from volumetric rates using trapezoidal interpolations between discrete depth intervals.

Acetate uptake rate constants were measured using the radiotracer method described by Wright and Hobbie [1966] and Lee [1992]. Water samples were collected as described above for the bacterial production assay. One hundred microliters of a nitrogen-purged solution of ${ }^{14} \mathrm{C}$-acetate $\left(4.4 \times 10^{6} \mathrm{dpm}\right.$ $\mathrm{mL}^{-1}$ ) were added to each vial using a gas tight syringe. Samples were incubated in the dark at in situ temperatures. At four time intervals (between 6 and 12 hours), vials were sacrificed by filtering duplicate $5 \mathrm{~mL}$ subsamples through $0.22 \mu \mathrm{m}$ polycarbonate Nuclepore filters to determine incorporation. Filters were placed in $20 \mathrm{~mL}$ scintillation vials containing $5 \mathrm{~mL} \mathrm{Op-}$ tiflor scintillation liquid. The remaining $30 \mathrm{~mL}$ sample was killed by addition of $0.5 \mathrm{~mL} 10 \mathrm{~N} \mathrm{KOH}$. The amount of acetate respired to carbon dioxide was measured later in the laboratory by acidifying the sample in a closed flask with filter soaked in $2 \mathrm{~N} \mathrm{KOH} \mathrm{[Wright} \mathrm{and} \mathrm{Hobbie,} \mathrm{1966;} \mathrm{Lee,} \mathrm{1992].}$

Settling carbon flux was measured with sediment traps. A mooring with four Mark-VII automated sediment traps [Honjo and Doherty, 1988] has been deployed at the CARIACO site in $1400 \mathrm{~m}$ of water since November 1995. The mooring has been retrieved and redeployed every 6 months, in May and November. Traps were positioned at approximately $275,455,930$, and $1225 \mathrm{~m}$ within the quiescent flow regime below sill depth. The cone-shaped traps had an aperture of $\sim 0.5 \mathrm{~m}^{2}$ cross section and had a baffle designed to minimize advective disturbances. Descending particles were funneled into a sample jar at its base. Each trap had 13 sampling jars filled with high-salinity water, 12 of which were poisoned with formalin. The jars were sequentially rotated beneath the trap by a microprocessorcontrolled stepping motor, which allows for sample collection over specified time intervals. We synchronized the computers to collect samples for concurrent 2 week periods at each depth. Upon retrieval, samples were split, and subsamples were subjected to a number of routine geochemical analyses to estimate carbonate, organic carbon, nitrogen, and biogenic silica fluxes. To estimate organic carbon, samples were dried, homogenized, weighed, and placed in silver boats. To eliminate inorganic carbon, boats were placed in a dessicator alongside a beaker of 

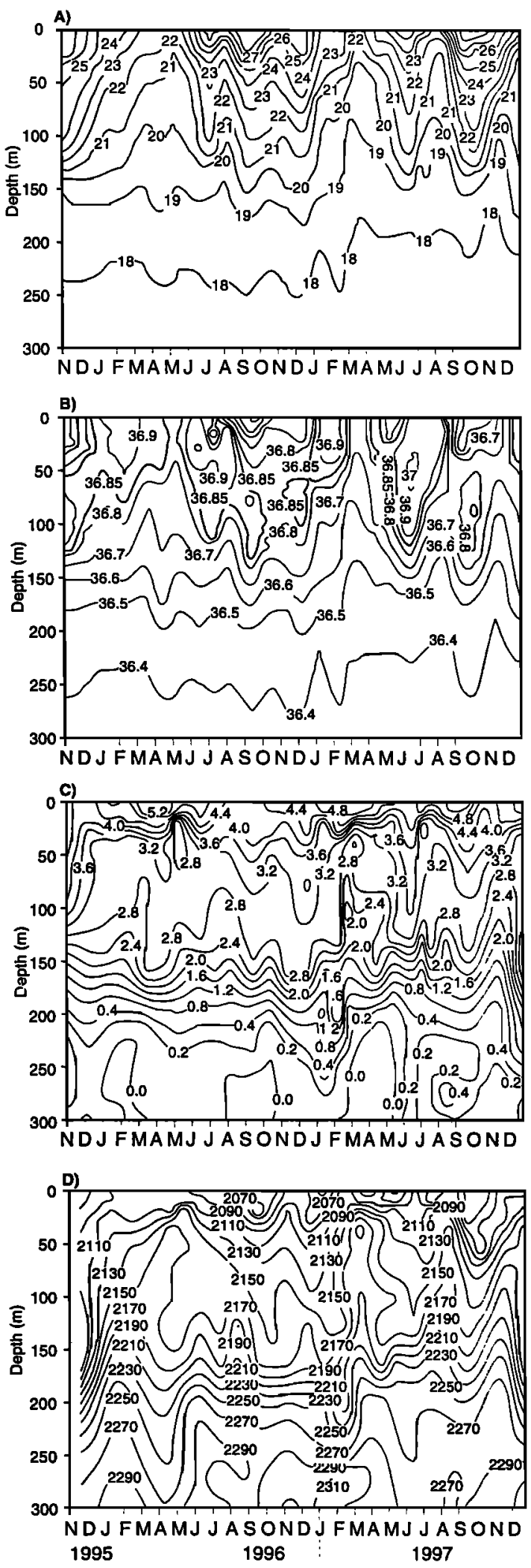

Figure 4. Seasonal variation in hydrographic properties at the CARIACO site: (a) temperature $\left({ }^{\circ} \mathrm{C}\right)$, (b) salinity, (c) oxygen $\left(\mathrm{mL} \mathrm{L}^{-1}\right)$, and (d) total DIC $\left(\mu \mathrm{mol} \mathrm{kg}{ }^{-1}\right)$.

concentrated $\mathrm{HCl}$ and put under a vacuum overnight. The samples were then folded and combusted in a PE2400 Elemental Analyzer. Cystine standard was used for calibration, and blank boats were used for determining background counts.
Another subsample was used for radioisotope and stable isotope determinations and organic geochemistry. Approximately half of each sample remained available for additional study.

\section{Results}

\subsection{Trade Wind}

Figure 3 shows variations in the wind experienced at Santiago Mariño Airport on Margarita Island, about $80 \mathrm{~km}$ to the northeast of the CARIACO station. The zonal component of the wind $(u)$ was almost identical to that observed about $15 \mathrm{~km}$ to the west at Punta de Piedras. At both locations the zonal component dominated variations in the wind, showing marked seasonality with values ranging from $4 \mathrm{~m} \mathrm{~s}^{-1}$ between about August and January to $10 \mathrm{~m} \mathrm{~s}^{-1}$ between about February and June. Muller-Karger and Aparicio [1994] compared the winds at Margarita Island with those observed at Orchila Island $200 \mathrm{~km}$ to the northwest. They concluded that variations in the zonal component of wind at Margarita are representative of those observed over the region.

The meridional component of the wind $(v)$ observed at the airport in Margarita was weaker, varying between about 0 and $1 \mathrm{~m} \mathrm{~s}^{-1}$. This component showed cyclic shifts with a period of about 3 months (Figure 3). Muller-Karger and Aparicio [1994] found that at both Margarita and Orchila Islands the meridional component of the wind stress was usually $<10 \%$ of the zonal component of stress, particularly if averaged over periods $>1$ month.

The trade winds were relatively weak (order of $4 \mathrm{~m} \mathrm{~s}^{-1}$ ) when we initiated the CARIACO program in November 1995 (Figure 3). Winds increased in December and January, peaked at $9-10 \mathrm{~m} \mathrm{~s}^{-1}$ in May 1996 , but decreased rapidly thereafter, dropping to $<5 \mathrm{~m} \mathrm{~s}^{-1}$ again in June 1996. Zonal winds remained relatively weak $\left(u \sim 5 \mathrm{~m} \mathrm{~s}^{-1}\right)$ in February-April 1997, but the meridional component showed substantial northward intensification ( $\left.v>2 \mathrm{~m} \mathrm{~s}^{-1}\right)$ at this time. Zonal winds increased to about $9 \mathrm{~m} \mathrm{~s}^{-1}$ in May-June, with a nil meridional component, but then $u$ decreased and $v$ increased after July. The trade winds remained weak $\left(<5 \mathrm{~m} \mathrm{~s}^{-1}\right)$ through the rest of the year, but they exhibited an anomalous northward component over this extended period $\left(\sim 1-2 \mathrm{~m} \mathrm{~s}^{-1}\right)$.

\subsection{Hydrography}

Between November 1995 and March 1996, surface temperatures decreased from $27.5^{\circ}$ to $23.0^{\circ} \mathrm{C}$ (Figure 3). The $21^{\circ} \mathrm{C}$ isotherm migrated from a depth of $\sim 130 \mathrm{~m}$ in November 1995 to $\sim 30 \mathrm{~m}$ by April 1996 (Figure 4a). In May 1996 the $22^{\circ} \mathrm{C}$ isotherm reached the surface. A peak in SST of $\sim 29.0^{\circ} \mathrm{C}$ was observed in September 1996. In 1997 an SST minimum of $21.5^{\circ} \mathrm{C}$ was observed in March as a result of the $21^{\circ} \mathrm{C}$ isotherm shoaling as early as January-February (Figure $4 \mathrm{a}$ ). In both years an SST decrease was observed in July and August (Figures 3 and $4 a$ ).

Features noted in the temperature data are evident in the other hydrographic parameters. From November 1995 through January 1996 the salinity maximum (36.9) rose from $\sim 100 \mathrm{~m}$ to the surface, and high surface salinities were observed until May 1996 (Figure 4b). A relatively fresh surface layer ( 36.3) appeared during August-October, while the salinity maximum retreated to $50-100 \mathrm{~m}$. Salinity isopleths turned upward again after October 1996, and the salinity maximum (>36.75) reached the surface again in January 1997. This situation persisted through March. Surface salinities between August and 
October were fresher $(<36.5)$, and temperatures were warmer, coincident with the onset of the rainy season.

Intrusions of Caribbean water, identified on the basis of oxygen data from the CTD profiler and the discrete (bottle) $\mathrm{O}_{2}$ and DIC data (Figures $4 c$ and $4 d$ ), were observed in January 1997 at 200-220 m, in June 1997 at $300 \mathrm{~m}$, in August 1997 at $275 \mathrm{~m}$, and in December 1997 at 220-240 m. The January 1997 event was not seen in the January bottle data but did appear in the February bottle data; it is possible that in January the bottle at $200 \mathrm{~m}$ missed this feature. In the months following an event the anomalous water mass could still be detected.

When an intrusion of water from outside the basin was detected, waters from depths above the intrusion were observed closer to the surface. This can be seen in Figures $4 \mathrm{c}$ and $4 \mathrm{~d}$, where isolines of oxygen and DIC are relatively flat in early 1997 below depths of $200 \mathrm{~m}$, while above those depths, water containing low oxygen values and high DIC are raised toward the surface, tracing the effects of an intrusion in January. The patterns of intrusion and the effects on hydrography and geochemistry are presented in more detail by Scranton et al. [2001] and Y. Astor et al. (manuscript in preparation, 2001).

A strong seasonal cycle was observed both for DIC (Figure 4d) and near-surface $\mathrm{CO}_{2}$ fugacity. The near-surface fugacity values during July-October of both 1996 and 1997 were typically in the 410-415 $\mu$ atm range. During January-May 1996 we observed surface values in the 385-390 $\mu$ atm range. During January-May 1997, values were smaller, typically between 370 and $390 \mu \mathrm{atm}$, with one observation of $\sim 335 \mu \mathrm{atm}$ in March.

\subsection{Chlorophyll and Primary Production}

A subsurface chlorophyll $a$ maximum $\left(\sim 0.4 \mathrm{mg} \mathrm{m}^{-3}\right)$ was located near $55 \mathrm{~m}$ in November 1995, but it rose to $25-30 \mathrm{~m}$ in December (Figure 5a). Between January and March 1996, values of $1.5-3.0 \mathrm{mg} \mathrm{m}^{-3}$ chlorophyll $a$ were observed in the upper $15 \mathrm{~m}$. In April and May, values in the upper $25 \mathrm{~m}$ exceeded $6 \mathrm{mg} \mathrm{m}^{-3}$ and reached $8 \mathrm{mg} \mathrm{m}^{-3}$ at $15 \mathrm{~m}$. Phytoplankton concentrations then decreased, reaching $<0.2 \mathrm{mg}$ $\mathrm{m}^{-3}$ by June at the surface. A small chlorophyll maximum $\left(\sim 0.4-0.8 \mathrm{mg} \mathrm{m}^{-3}\right)$ remained at about $35-55 \mathrm{~m}$ through October.

This cycle was repeated in 1996-1997, but the bloom started earlier than in 1995-1996, with biomass values of $\sim 4 \mathrm{mg} \mathrm{m}^{-3}$ seen at $25 \mathrm{~m}$ in November 1996 (Figure 5a). After a brief decline in chlorophyll $a$ to $<1 \mathrm{mg} \mathrm{m}^{-3}$ in the upper $20 \mathrm{~m}$ in December 1996 a bloom reformed in January 1997 with 3-5 mg $\mathrm{m}^{-3}$ in the upper $25 \mathrm{~m}$ and lasted through May.

Surface particulate organic matter also increased tenfold between November 1995 (40-50 $\mathrm{mgC} \mathrm{m}^{-3}$; particulate organic nitrogen $(\mathrm{PON}) \sim 2.5 \mathrm{mgN} \mathrm{m}^{-3}$ ) and March 1996 (500-800 $\mathrm{mgC} \mathrm{m} \mathrm{m}^{-3}, \mathrm{PON}>60 \mathrm{mgN} \mathrm{m}^{-3}$ ). POC and PON reached a peak during May 1996, but unlike chlorophyll, which declined in June 1996, POC (and dissolved organic carbon (DOC)) remained high until July 1996 . We also commonly observed a minimum in POC $\left(10-20 \mathrm{mgC} \mathrm{m}^{-3}\right)$ just above the oxic-anoxic interface throughout the year. Concentrations around the interface at $275 \mathrm{~m}$ were higher but variable $\left(20-70 \mathrm{mgC} \mathrm{m}^{-3}\right)$. Lower but also variable concentrations $\left(25-50 \mathrm{mgC} \mathrm{m}^{-3}\right)$ were observed in deeper waters $(>275 \mathrm{~m})$.

Primary productivity showed marked seasonality (Figure $5 b)$. Between about July and December, rates were $<2.5 \mathrm{mg}$ $\mathrm{m}^{-3} \mathrm{~h}^{-1}$ in the upper $30 \mathrm{~m}$, with lowest values $\left(<1.0 \mathrm{mg} \mathrm{m}^{-3}\right.$ $h^{-1}$ ) in August and September of both 1996 and 1997. Deeper waters typically showed values of $<0.3 \mathrm{mg} \mathrm{m}^{-3} \mathrm{~h}^{-1}$. Rates increased tenfold during January through June of both years, with values reaching $15 \mathrm{mg} \mathrm{m}^{-3} \mathrm{~h}^{-1}$ and on occasion $20-40$ $\mathrm{mg} \mathrm{m}^{-3} \mathrm{~h}^{-1}$ in the upper $7 \mathrm{~m}$. The change in incubation time, from $0600-1000$ to $0700-1100$ LT, starting in January 1996 caused a small decrease only in the surface $(1 \mathrm{~m})$ primary productivity estimates.

Depth-integrated $(0-100 \mathrm{~m})$ primary production changed substantially over the course of our 1996-1997 field effort (Figure 6), in part because the annual cycle was punctuated by strong events. The average depth-integrated production between January and May 1996 was about $2800 \mathrm{mg} \mathrm{C} \mathrm{m}^{-2} \mathrm{~d}^{-1}$, which was heavily influenced by the May 1996 upwelling event. During the same period in 1997 it was about $2600 \mathrm{mg} \mathrm{C} \mathrm{m}^{-2}$ $\mathrm{d}^{-1}$. Productivity during June-December was lower $(\sim 1000$ $\mathrm{mg} \mathrm{C} \mathrm{m} \mathrm{m}^{-1}$ in 1996 and $\sim 860 \mathrm{mg} \mathrm{C} \mathrm{m}^{-2} \mathrm{~d}^{-1}$ in 1997) (Figure 6). Integrated production in 1996 was $\sim 500$ (not counting May) to $690 \mathrm{gC} \mathrm{m}^{-2} \mathrm{yr}^{-1}$ (if May is included). In comparison, production in 1997 was between 480 (not counting January) and $540 \mathrm{gC} \mathrm{m}^{-2} \mathrm{yr}^{-1}$ (counting January).

The assimilation number $P^{B}$ (amount of carbon fixed per unit chlorophyll) is shown in Figure $7 . P^{B}$ at $7 \mathrm{~m}$ was typically the highest throughout the series and was likely the closest to $P_{\max }^{B}$. Average $P^{B}$ at $7 \mathrm{~m}$ during January-June was about $7 \mathrm{mg}$ $\mathrm{C} \mathrm{mg} \mathrm{Chl}{ }^{-1} \mathrm{~h}^{-1}$ (range 4.6-9.0 mg C mg Chl ${ }^{-1} \mathrm{~h}^{-1}$ ), and during July-November it was $12 \mathrm{mg} \mathrm{C} \mathrm{mg} \mathrm{Chl}^{-1} \mathrm{~h}^{-1}$ (range 7.5-14 $\left.\mathrm{mg} \mathrm{C} \mathrm{mg} \mathrm{Chl}^{-1} \mathrm{~h}^{-1}\right)$. Surface $(1 \mathrm{~m}) P^{B}$ was generally 6-14 $\mathrm{mg} \mathrm{C} \mathrm{mg} \mathrm{Chl}^{-1} \mathrm{~h}^{-1}$ prior to December 1996 and decreased to 4-9 $\mathrm{mg} \mathrm{C} \mathrm{mg} \mathrm{Chl}{ }^{-1} \mathrm{~h}^{-1}$ afterward (not shown). This is likely due to increased photoinhibition in the surface incubation bottles caused by the later incubation times. This effect was not apparent in deeper samples.

\subsection{Vertical Organic Carbon Flux}

The first 6 months of sediment trap samples were retrieved successfully in May 1996. Unfortunately, samples for the following 6 months were lost. The four traps clogged immediately after redeployment of the mooring, resulting in a data gap in the sediment flux series from May-November 1996. We attribute this to unusually high particle fluxes caused by the large plankton bloom of May 1996 (see Figures 5 and 6). Subsequent redeployments, in November 1996 and May 1997, were successful.

The vertical flux of organic carbon followed a regular pattern, with minima between September and January, maxima between February and May, and similar temporal variability at all four depths (Figure 8). In 1996, carbon flux showed a minimum of $\sim 0.01 \mathrm{gC} \mathrm{m}^{-2} \mathrm{~d}^{-1}$ in January at all four trap depths (Figure 8). Flux increased in the subsequent 2 months to peak in March 1996 at $0.17 \mathrm{gC} \mathrm{m}^{-2} \mathrm{~d}^{-1}$ at $275 \mathrm{~m}$ and at about $0.06 \mathrm{gC} \mathrm{m}^{-2} \mathrm{~d}^{-1}$ at $1225 \mathrm{~m}$. The largest organic carbon flux recorded in this 2 year period was seen in the $1225 \mathrm{~m}$ trap sample for early July 1997 and was associated with a turbidite generated by an earthquake that occurred along the Venezuelan coast [Thunell et al., 1999]. Otherwise, the highest flux $\left(0.18 \mathrm{gC} \mathrm{m}^{-2} \mathrm{~d}^{-1}\right)$ was observed in the shallowest trap in May 1997. In general, organic carbon flux decreased from the shallowest to the deepest trap. The $275 \mathrm{~m}$ trap usually exceeded the flux captured at $455 \mathrm{~m}$ by $20-200 \%$ during January-May and frequently by $200-400 \%$ during July-November periods. However, in $27 \%$ of collections the flux to the $455 \mathrm{~m}$ trap matched or slightly exceeded the flux observed in the shallowest $(275 \mathrm{~m})$ trap. 

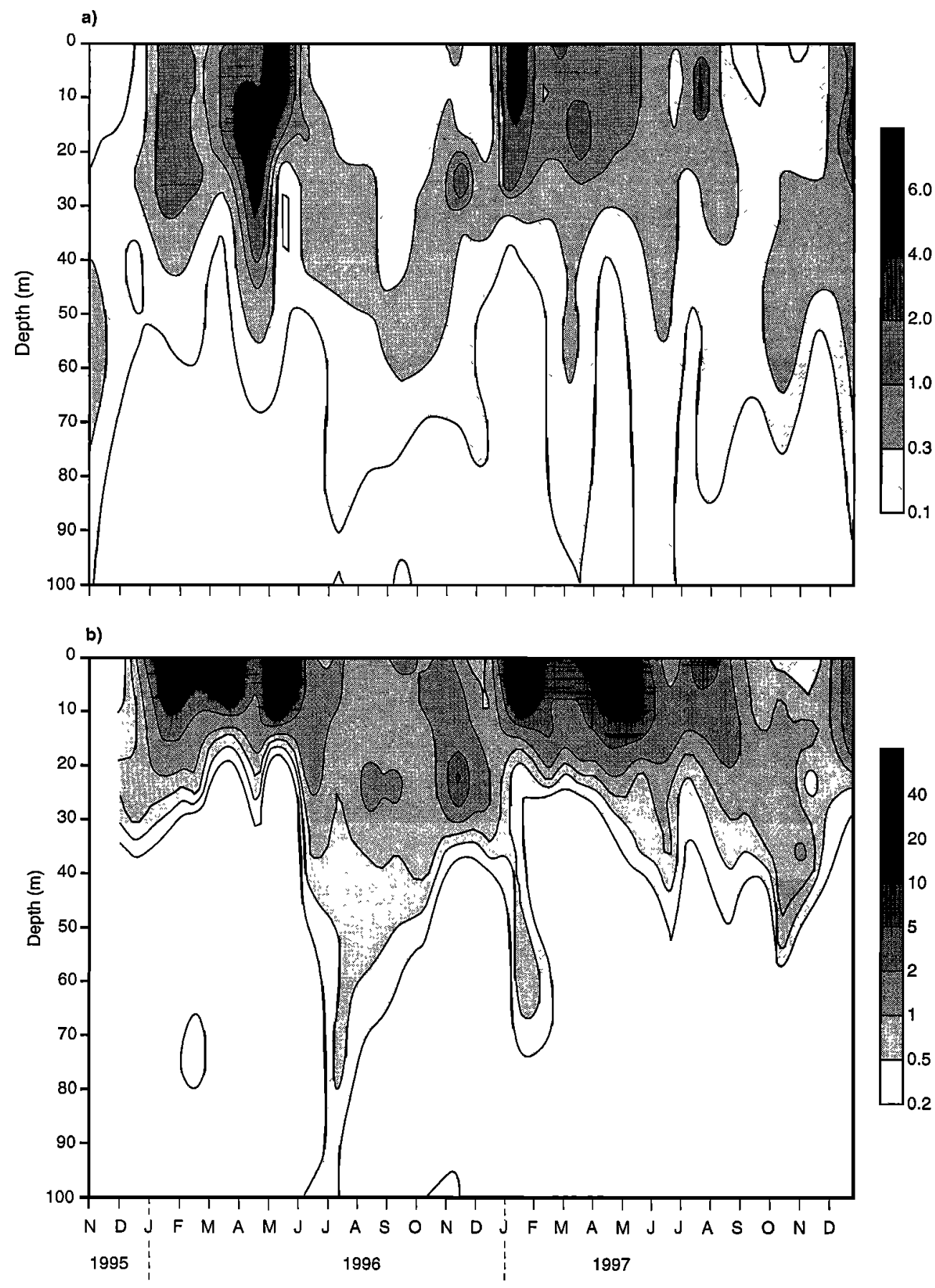

Figure 5. Seasonal variation in (a) chlorophyll concentration $\left(\mathrm{mg} \mathrm{m}^{-3}\right)$ and (b) primary production (mg $\mathrm{m}^{-3} \mathrm{~h}^{-1}$ ) over the upper $100 \mathrm{~m}$ at the CARIACO site from December 1995 through December 1997.

\subsection{Bacterial Production}

Bacterial abundance, bacterial productivity, acetate concentration and acetate uptake rate constants, and dark carbon fixation rates were measured on six cruises between November 1995 and December 1997, and bacterial production was measured on an additional five cruises. The distributions seen for May 1997 (Figures 9 and 10) were similar to those observed on other dates. The most noticeable feature in the profiles is the low bacterial activity throughout the water column except at the surface and at the oxic-anoxic interface. Rates of bacterial activity (leucine incorporation and acetate uptake) near the oxic-anoxic interface often are comparable to rates in the surface mixed layer.

\section{Discussion}

The Cariaco Basin serves as a unique laboratory to examine the sinking flux of material because it forms a natural sediment trap. Outside the Cariaco Basin, materials that sink from surface waters and reach the deep parts of the Caribbean Basin 


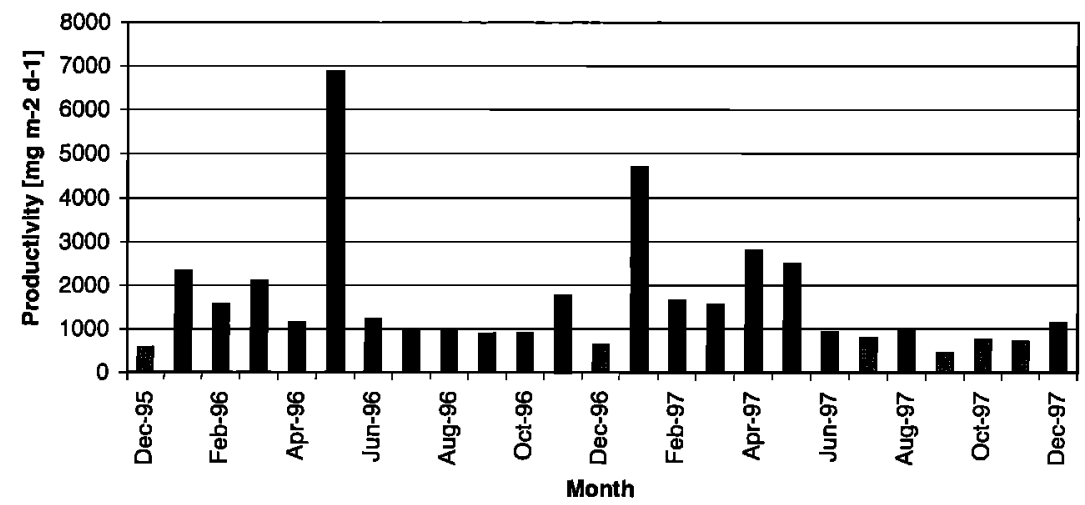

Figure 6. Cariaco Basin daily primary production integrated over the upper $100 \mathrm{~m}\left(\mathrm{mg} \mathrm{C} \mathrm{m}^{-2} \mathrm{~d}^{-1}\right)$.

may be trapped there for periods of at least $50-800$ years [Redfield et al., 1963; Kinder et al., 1985]. However, sinking material is quickly dispersed because of the strong Caribbean Current that washes the South American continental margin. Because of the strong currents along this margin, this flux is hard to measure. Waters in the Cariaco Basin have comparable residence times [Deuser, 1973], but material sinks near its place of origin. In either case the important quantity is the amount of material that is incorporated into the sediments because this material may be sequestered for periods spanning multiple centuries or millenia [Haug et al., 1998; Hughen et al., 1998; Black et al., 1999].

The results from the CARIACO series site demonstrate that production along continental margins in the tropics can be substantial and, indeed, redefines earlier estimates as being minimum values. Our annual production estimates (500-690 $\mathrm{gC} \mathrm{m}^{-2} \mathrm{yr}^{-1}$ ) are higher than those reported previously from the vicinity of the Cariaco Basin $\left(200-400 \mathrm{~g} \mathrm{C} \mathrm{m}^{-2} \mathrm{yr}^{-1}\right)$ [Ballester and Margalef, 1965; Curl, 1960; Richards, 1960]. These values are comparable to those estimated for Monterey Bay ( 7 year average of $\sim 460 \mathrm{gC} \mathrm{m}^{-2} \mathrm{yr}^{-1}$ ) [see Olivieri and Chavez, 2000; Chavez, 1996] and considerably higher than those estimated for Georges Bank, the New York Shelf, and the Oregon Shelf $\left(380,300\right.$, and $190 \mathrm{gC} \mathrm{m}^{-2} \mathrm{yr}^{-1}$, respectively) [Walsh, 1988]. Previous estimates of production in the Cariaco Basin may be lower either because they were obtained by indirect methods [Richards, 1960; Curl, 1960] or derived from sparse temporal data that missed production peaks [Ballester

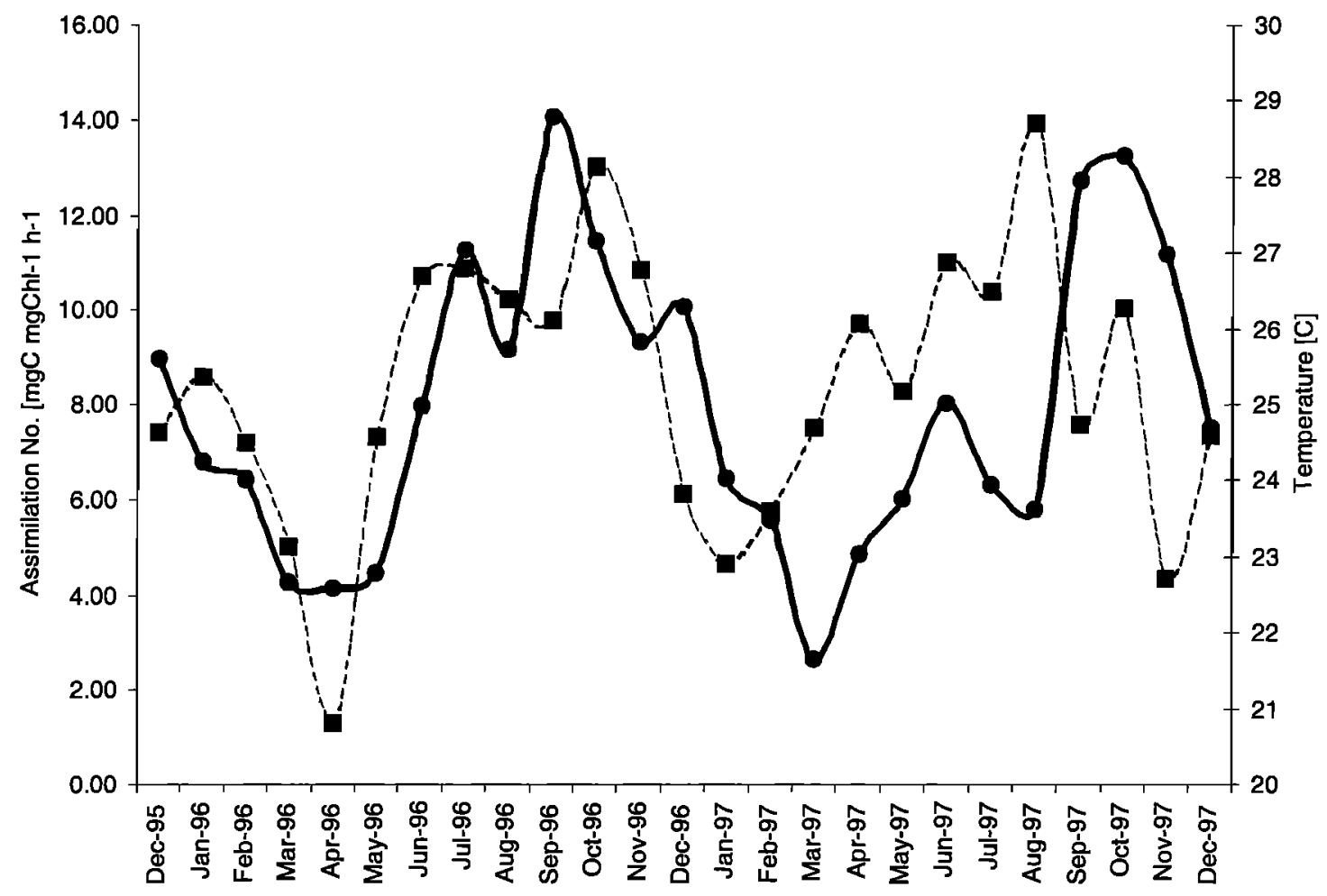

Figure 7. Time series of water temperature at $7 \mathrm{~m}$ measured with a CTD (solid line, circles $\left({ }^{\circ} \mathrm{C}\right.$ )) and of the assimilation number $P^{B}$ at $7 \mathrm{~m}$ (broken line, squares) at the CARIACO station between December 1995 and December 1997. 


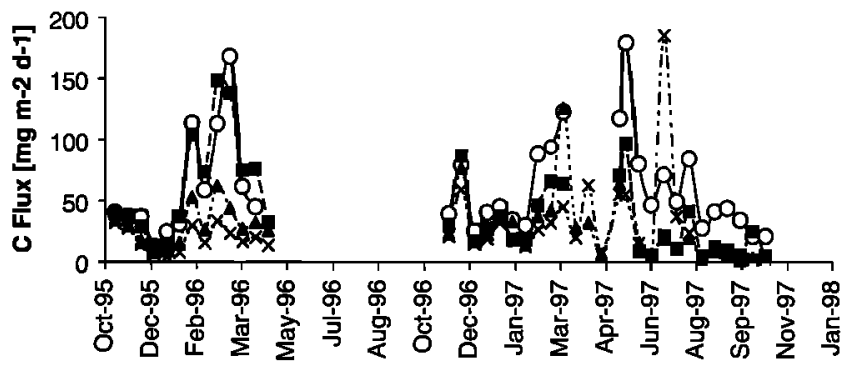

Figure 8. Time series of biweekly integrations of organic carbon flux observed with sediment traps $\left(\mathrm{mgC} \mathrm{m}^{-2} \mathrm{~d}^{-1}\right)$ at 275 (open circles, solid line), 455 (squares, broken line), 930 (triangles, stippled line), and $1225 \mathrm{~m}$ (crosses) at the CARIACO site.

and Margalef, 1965]. Clearly, previous workers have been unable to evaluate variability in carbon fixation rates in the Cariaco Basin because few observations were available.

\subsection{Water Mass Exchange and Upwelling}

Why is the southern Caribbean Sea so productive? Upwelling along the southern Caribbean, and specifically its impact within the perimeter of Cariaco, has been discussed by Richards [1960], Margalef et al. [1960], Margalef [1965], Ballester and Margalef [1965], Morris et al. [1981], Febres-Ortega and Herrera [1975], Herrera and Febres-Ortega [1975], and Walsh et al. [1999] among others. Studies with Coastal Zone Color Scanner (CZCS) imagery show that the most pronounced blooms take place over the eastern portion of the Cariaco Basin [Muller-Karger et al., 1989; Muller-Karger and Aparicio, 1994]. Both ocean color (CZCS and Sea-viewing Wide Field-of-view Sensor (SeaWiFS)) and AVHRR satellite data show that the upwelling plume extends over $4 \times 10^{4} \mathrm{~km}^{2}$ and sometimes reaches $>9 \times 10^{4} \mathrm{~km}^{2}$.

Historical sections of salinity across the Caribbean Sea [Morrison and Smith, 1990, and references therein] show a northsouth trend in salinity at the level of the salinity maximum ( 36.85) associated with Subtropical Underwater (SUW). SUW lies between 100 and $200 \mathrm{~m}$ depth north of $14.5^{\circ} \mathrm{N}$ and shallower than $150 \mathrm{~m}$ south of $14.5^{\circ} \mathrm{N}$. This upward tilt in the SUW layer is emphasized during the first half of the year relative to the second half of the year. Figure $4 \mathrm{~b}$ shows the vertical excursion of the 36.85 isohaline in the Cariaco Basin, which is at the southern extreme of this tilting layer. Within the SUW, nitrate is 5-10 $\mu \mathrm{M}$ [Morrison and Nowlin, 1982], and as this water is brought to the surface in the Cariaco Basin during the first half of the year, it leads to elevated nutrients in the upper water column, thus stimulating phytoplankton growth.

The current conceptual model of upwelling in the southern Caribbean Sea directly associates surface Ekman transport driven by the trade winds to an upward migration of the thermocline along the (roughly) east-west oriented coast that defines this continental margin. This conceptual model has been used without rigorous testing in studies of modern processes [e.g., Muller-Karger and Aparicio, 1994] and paleo-oceanographic studies [e.g., Haug et al., 1998; Hughen et al., 1998; Black et al., 1999].

Upon closer examination, however, some years show a lag between the onset of upwelling as traced by a decrease in SST in Figure 3 (or the rise in the SUW in Figure 4) and the seasonal strengthening of the trade winds (Figure 3). For ex- ample, rapid cooling occurred between October 1995 and January 1996 and again between October 1996 and January 1997, prior to any significant increase in zonal wind speed above 5-6 $\mathrm{m} \mathrm{s}^{-1}$. Similarly, every year, SST started increasing prior to, or coincident with, the onset of the seasonal weakening of the trades, while zonal wind speeds were still in excess of $7 \mathrm{~m} \mathrm{~s}^{-1}$ (Figure 3). Even though there appeared to be small decreases in SST associated with the cyclic increase in the northward component of the trade wind (Figure 3), there was no clear evidence that the larger seasonal changes seen in the hydrography and SST were driven solely by the local wind.

At this time, there is no conclusive explanation for the outof-phase changes in hydrography relative to the wind. For the Caribbean Sea a hypothesis may be that the vertical displacement of the SUW in the southern Caribbean is controlled by seasonal changes in the geostrophic flow through the basin [see, e.g., Morrison and Nowlin, 1982; Morrison and Smith, 1990]. Such changes in the meridional slope of the isopleths are likely connected to remote processes. We may speculate that the circulation through the Lesser Antilles is strongly affected by the seasonal switch between strong combined inflow from the North Equatorial Current and the Guiana Current between January and June and weaker flow between June and about December, when the North Equatorial Countercurrent and the North Brazil Current Retroflection form [see Muller-Karger et al., 1995, and references therein]. These changes would provide the correct phase relative to the wind in the southern Caribbean. In addition, the seasonal cycle in the Cariaco Basin may be superimposed on larger interannual variation in the flow through the various passages in the $\mathrm{Ca}$ ribbean Sea [see Murphy et al., 1999].

At shorter timescales of 2-3 months, small variations in the hydrography were apparent, particularly in 1996 . These variations included relatively small oscillations in isotherms, isohalines, and oxygen concentrations to a depth of about $150 \mathrm{~m}$ (Figure 4). They were also reflected as roughly $1^{\circ} \mathrm{C}$ changes in the smoothed satellite-derived SST series. Starting in 1997, the depth amplitude of such variations was more pronounced, and marked changes in oxygen and DIC were observed repeatedly between $200 \mathrm{~m}$ and the surface. These variations are likely due,

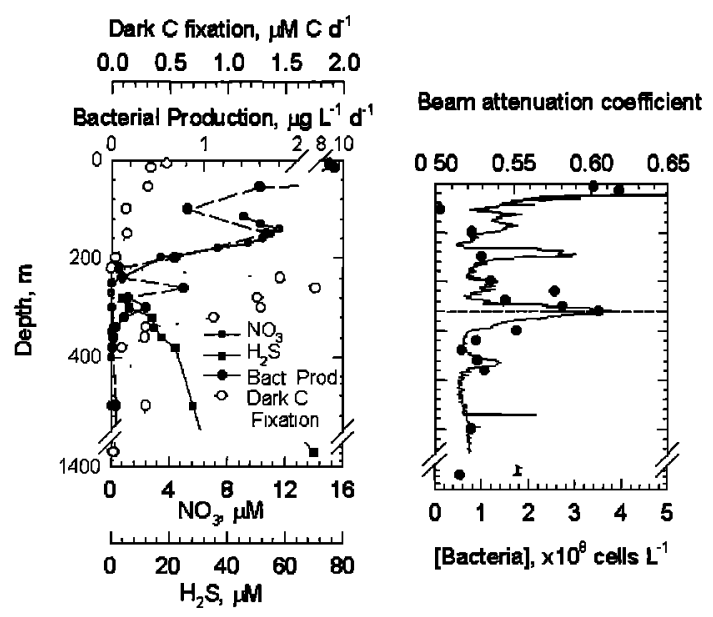

Figure 9. (left) Vertical profiles of bacterial net production, dark carbon fixation, and nitrate and hydrogen sulfide concentration measured in the Cariaco Basin in May 1997. (right) Bacterial cell counts (circles) and continuous profile from a SeaTec transmissometer for May 1997. 

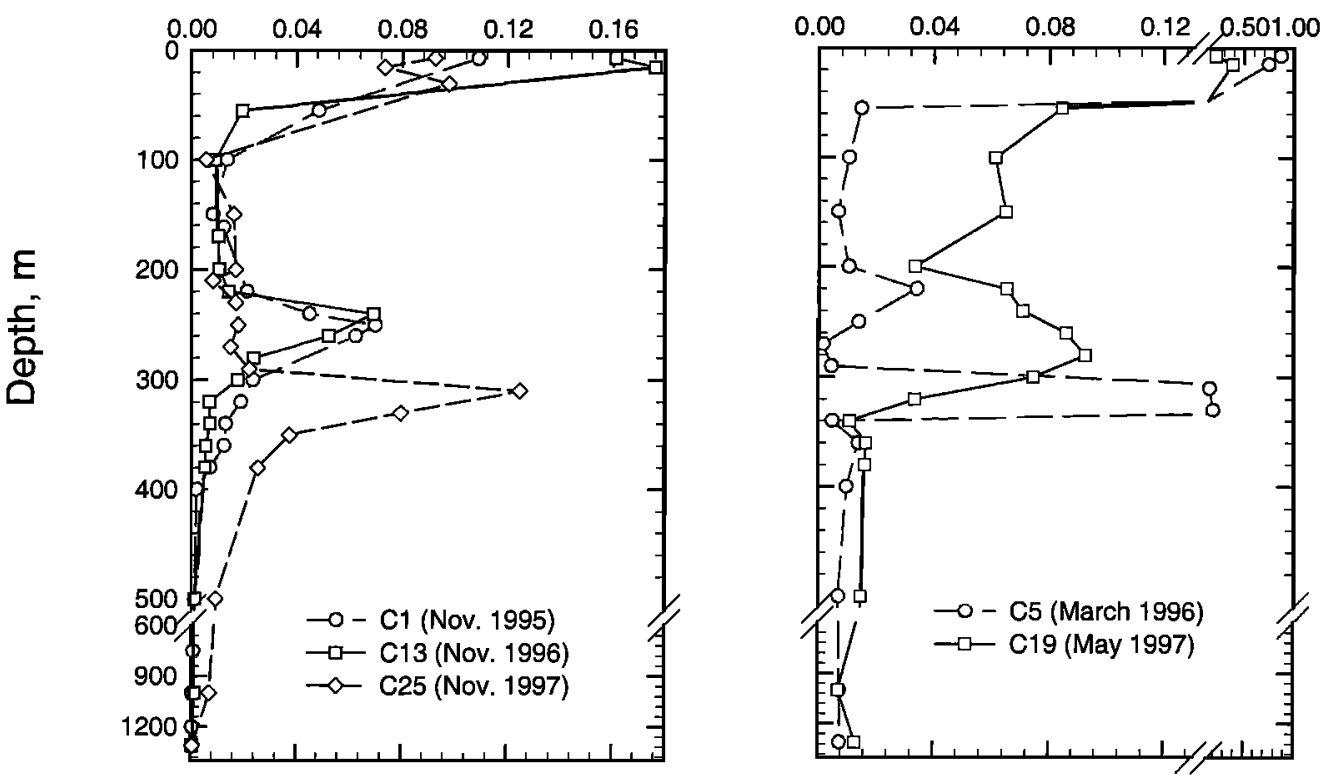

Figure 10. Vertical profiles of the total acetate uptake rate constant (respiration plus incorporation) in the Cariaco Basin. This rate is higher throughout the water column during upwelling (March and May) relative to nonupwelling seasons (November). The depth of the uptake rate maximum is usually closely related to the depth of the oxic-anoxic interface.

at least in part, to intrusion of Caribbean water into the Cariaco Basin at or near sill depth.

The intrusion of deeper water (below SUW) from the Caribbean Sea into the Cariaco Basin is dependent on this water being present at sill depth, a situation that occurs during the first half of the year [see Morrison and Smith, 1990]. When the influx is large, it may be classified as a ventilation event because it brings substantial oxygen into the deeper, oxygen-poor waters in the basin. Intrusions are probably more likely during times when the SUW layer tilts upward toward the southern Caribbean margin [e.g., Morrison and Smith, 1990], i.e., between about December and the following June.

There is at this time no definitive explanation for the 2-3 month signal observed in the 1996 hydrography nor for the repeated ventilations of 1997 . There is a 2-3 month variation in the meridional component of the wind (Figure 3), which even though is of a small amplitude $\left(\sim 1-2 \mathrm{~m} \mathrm{~s}^{-1}\right)$, may play a role in these fluctuations (Figure 4 ). Another possible scenario is that the hydrography of the shelf was affected by eddies moving west in the Caribbean Current. A synoptic view of these eddies and their relation to the wider circulation in the Caribbean Sea has emerged from recent numerical models of the Caribbean Basin and from satellite altimeter data [Murphy et al., 1999; Carton and Chao, 1999]. Once an intrusion or ventilation event occurs, the local wind assists in further elevating the SUW layer and in enhancing mixing, thereby lowering the temperature further along the coastline. A detailed discussion of the deep geochemical effects of intrusions is provided by Scranton et al. [2001], and a more detailed description of the hydrographic effects is presented by Y. Astor et al. (manuscript in preparation, 2001).

\subsection{Primary Production}

Similar to the pattern observed in SST, seasonal changes in primary productivity precede changes in the wind. Figure $5 \mathrm{~b}$ shows that higher surface productivity $\left(>2 \mathrm{mg} \mathrm{m}^{-3} \mathrm{~h}^{-1}\right)$ was observed as early as December-January, 1-2 months prior to substantial increases in the westward wind speed. Productivity tracked temperature changes, which is a proxy for nutrient availability. In 1997, production was sustained at a higher level and for a longer period relative to 1996 because of waters with higher nutrients being pushed toward the surface from below by a strong ventilation event [see Scranton et al., 2001; Y. Astor et al., manuscript in preparation, 2001].

The biomass specific carbon uptake rates $P^{B}$ were close to the physiological maximum, which suggests that phytoplankton were growing at near-maximum specific growth rates throughout the year and that there was no nutrient limitation in the Cariaco Basin during the upwelling season. Nevertheless, there was a distinct seasonal variation in $P^{B}$ (Figure 7). While $B e$ hrenfeld and Falkowski [1997] suggest that $P^{B}$ should decrease above about $20^{\circ} \mathrm{C}, P^{B}$ at CARIACO increased with temperature over the seasonal temperature range of $21^{\circ}-29^{\circ} \mathrm{C}$. This is likely to be due in part to the temperature effect described by Eppley [1972] and not to a nutrient effect. At CARIACO, nutrients follow an inverse relationship to SST, and $P^{B}$ should decrease with a decrease in nutrient concentrations. There is also an inverse relationship between $P^{B}$ and biomass, suggesting that succession favored organisms with higher specific growth rates during periods of lower nutrient availability. $P^{B}$ in 1997 showed increased variability relative to the 1996 observations possibly because of an interaction between increased photoinhibition caused by the change in incubation time and nutrient supply due to increased (but variable) upwelling.

\subsection{Sinking Organic Carbon Flux}

Because of their high productivity, surface waters are a source of organic carbon to deeper water. While we have not measured vertical velocities of the water being upwelled at the CARIACO station, a numerical model developed by Walsh et al. [1999] suggested upward vertical speeds of $1-2 \mathrm{~m} \mathrm{~d}^{-1}$ under westward winds of $6-10 \mathrm{~m} \mathrm{~s}^{-1}$, compared to $5-10 \mathrm{~m} \mathrm{~d}^{-1}$ about 


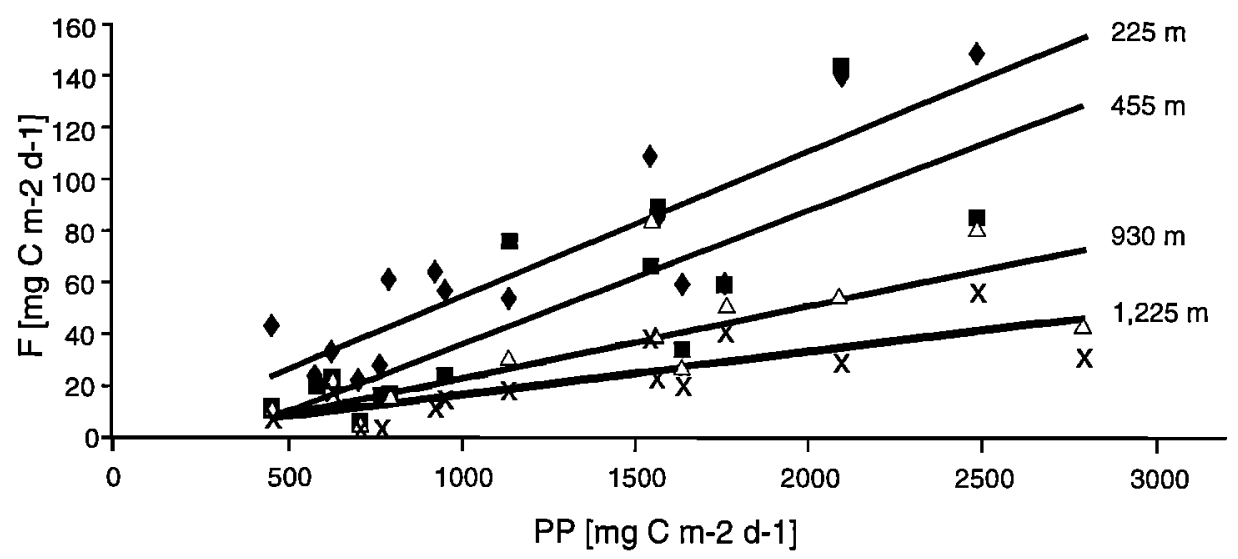

Figure 11. Relationship between monthly values of daily depth-integrated primary production (mgC m $\mathrm{m}^{-2}$ $\mathrm{d}^{-1}$ ) and monthly means of the biweekly integrations of organic carbon flux $\left(\mathrm{mgC} \mathrm{m}^{-2} \mathrm{~d}^{-1}\right.$ ) at 275 (diamonds), 455 (squares), 930 (triangles), and $1225 \mathrm{~m}$ (crosses) at the CARIACO site. Lines are least squares regressions. January 1996 and 1997 were not included in the regressions as these were considered to be possible outliers in production.

$20 \mathrm{~km}$ closer to shore along the Venezuelan coast. With a prescribed thermocline depth representing conditions for the first half of the year, i.e., when the SUW layer is closer to the surface in the southern Caribbean, results suggested that the vertical upward displacement velocities decreased to the north (and west) of the CARIACO station. Nil displacements were simulated near the sill, which is located within $100 \mathrm{~km}$ of the station. Therefore, even if the actual sinking rates for particulate matter at CARIACO were much less than $100 \mathrm{~m} \mathrm{~d}^{-1}$ [Deuser et al., 1990], it is likely that the sediment traps, located below the $140 \mathrm{~m}$ sill depth, are within the statistical cone of sinking flux [Deuser et al., 1990] that originates at the station. We assume that vertical settling of particles dominates horizontal losses within this statistical funnel.

As mentioned above, the settling POC flux in the Cariaco Basin followed an annual cycle similar to that of surface production (see Figures 6 and 8). The flux of opaline silica was tightly coupled with organic carbon flux, and the $C / N$ and $\delta^{13} \mathrm{C}_{\text {org }}$ values for the sediment trap samples mostly varied from 5.8 to $7.9 \mathrm{vol} / \mathrm{vol}$ and from -18.0 to $-22.5 \%$, respectively [Thunell et al., 2000]. This is consistent with the idea that the material reaching the bottom of Cariaco was diatomaceous in origin and that the flux of terrigenous material into the middle of the Cariaco Basin was small at all times of year [Thunell et al., 2000].

Vertical carbon flux was directly proportional to integrated production (Figure 11), with the magnitude of the flux usually decreasing with depth. Carbon flux at $275 \mathrm{~m}$ was on the average $5.6 \%$ of integrated primary production. This decreased to $5.1 \%$ at $455 \mathrm{~m}$, although in February, March, and April 1996 it was essentially the same at both 275 and $455 \mathrm{~m}$ at $6-7 \%$. The average proportion decreased to $2.8 \%$ at $930 \mathrm{~m}$ and to $1.7 \%$ at $1225 \mathrm{~m}$. One of the effects of the decrease in the ratio of settling carbon flux to primary productivity with increasing depth is a marked change in the difference of the flux between 225 and $1225 \mathrm{~m}$ with time. Specifically October, November, and December (low flux months) feature the smallest vertical differences in the flux, while March-May (high flux months) show large differences (see Figure 8). This implies that during the spring bloom, remineralization of the sinking organic matter is more efficient than during the nonupwelling season.
Acetate uptake rate constants (respiration plus incorporation; Figure 10) also provide a measure of organic remineralization under low-oxygen conditions [Henrichs, 1993]. Rate constant profiles consistently showed a strong maximum at the oxic-anoxic interface. In addition, rate constants for upwelling seasons (March and May) were higher than rate constants measured during November and July (data for July not shown). The abrupt deepening of the acetate uptake rate constant maximum in November 1997 as compared to other dates was associated with a similar deepening of the oxic-anoxic interface caused by the repeated intrusions of 1997 described above [Scranton et al., 2001]. These data support the conclusions from the sediment traps that more organic matter is respired during upwelling periods than during quiescent periods at all depths.

On the basis of the rate of decrease of fluxes with depth it appears that almost $95 \%$ of the particulate carbon produced by phytoplankton near the surface is consumed or regenerated within the upper $275 \mathrm{~m}$ of the water column. This can be compared to about 86-98\% in Monterey Bay [Pilskaln et al., 1996] and $84-93 \%$ in the Santa Barbara Basin [Thunell, 1998b]. Our observed carbon fluxes are in excellent agreement $\left(r^{2}=0.87\right)$ with predicted fluxes determined using the Pace et al. [1987] model developed for the eastern Pacific Ocean and suggest that organic matter degradation occurring in an anoxic water column is as efficient as that occurring in welloxygenated waters [see Thunell et al., 2000].

Suspended POC also decreases sharply with depth even during the high production season, from values in excess of $200 \mathrm{mg}$ $\mathrm{m}^{-3}$ in the upper $25 \mathrm{~m}$ to $<50 \mathrm{mg} \mathrm{m}^{-3}$ below $50 \mathrm{~m}$. The vertical distribution of bacteria and bacterial activity (Figure 9) suggests that an active biological population is located at the oxic-anoxic interface. While not associated with any apparent increase in bacterial biomass, a secondary maximum in bacteria productivity between 100 and $160 \mathrm{~m}$ suggests that intensive carbon cycling also takes place in this depth range (Figure 9). Peaks in bacterial activity are commonly found at the oxicanoxic transition zone in many environments.

While most of the bacterial production occurs in the upper $275 \mathrm{~m}$, a significant fraction occurs below this depth. Our data show that $4-37 \%$ of integrated bacterial production (mean = 17\%; standard deviation $=11$ ) can occur below the depth of 
the top sediment trap $(275 \mathrm{~m})$. This is in contrast with the sediment trap data, which imply that on average, $95 \%$ of the labile export production is consumed or regenerated at depths shallower than $275 \mathrm{~m}$ and therefore that $<5 \%$ sinks below this depth. However, bulk carbon delivery to the $455 \mathrm{~m}$ trap exceeded that delivered to the $275 \mathrm{~m}$ trap in $27 \%$ of our observations. Furthermore, on average we observe as much, and frequently more, bacterial production between 275 and $450 \mathrm{~m}$, below the oxic-anoxic interface (17\% integrated bacterial production), as in the overlying $175 \mathrm{~m}$ (14\% integrated bacterial production).

Clearly, the interface is a region of vigorous carbon cycling fueled by labile carbon. We propose that this carbon is not necessarily provided by surface-derived export production. While bulk carbon delivery to the deepest trap appeared to conform to open water predictions [Thunell et al., 2000], the composition and source terms for this material are not well defined. Rapid heterotrophic activity at the oxic-anoxic interface suggests introduction of fresh labile organic matter at depth either through vertical migrators or possibly through in situ production by chemoautotrophs. Biologically enhanced layers established by either accumulation of particles along isopycnals or lateral advection of more productive waters are less likely explanations in the Cariaco Basin because waters below $200 \mathrm{~m}$ have nearly constant density and waters across the interface consistently have a uniform temperature-salinity $(T-S)$ signature. Furthermore, these biologically enhanced layers are persistent features, and flux anomalies do not appear to correspond to the intrusions reported above. If in situ production at the interface contributes significantly to the vertical flux, then total fluxes to the seafloor and the chemical and stable isotopic composition of this material may be decoupled from surface processes.

Eppley and Peterson [1979] found that in the deep ocean the fraction of new to total production grows as total production increases. One of our early goals in the CARIACO program was to test this hypothesis at our continental margin site. For this purpose we may assume that the vertical organic carbon flux observed at the CARIACO station represents new production (export production equals new production) and that our productivity estimates are an approximation of total production. While there was seasonal variation in the settling organic carbon flux, there was no noticeable seasonality in the proportion of vertical flux to primary production. Indeed, the $e$ ratio was relatively constant to within a few percent at any of the trap depths (Figure 11). In Monterey Bay [Pilskaln et al., 1996] and in the Santa Barbara Basin [Thunell, 1998b] the $e$ ratio decreased as primary productivity increased. At these sites off California this result was interpreted as an effect of lateral advection. In any event, this suggests that Eppley and Peterson's [1979] relationship applies primarily to areas of lower productivity and not to continental margins.

The trap and primary productivity observations suggest then that between 10 and $11 \mathrm{gC} \mathrm{m}^{-2}$ are delivered to the bottom sediment of Cariaco every year. This agrees well with the 7-8 $\mathrm{gC} \mathrm{m}^{-2}$ seen at $2300 \mathrm{~m}$ at other continental margin locations [cf. Walsh, 1991; Pilskaln et al., 1996; Etcheber et al., 1996; Thunell, 1998b]. Preservation of organic matter within the anoxic environment of the Cariaco Basin therefore does not seem to be either enhanced or diminished relative to that of other continental margins [Thunell et al., 2000].

If these annual rates of carbon delivery to the bottom (10-11 $\mathrm{gC} \mathrm{m}^{-2} \mathrm{yr}^{-1}$ ) apply over the upwelling plume that covers the
Cariaco Basin and adjacent areas, which can be estimated to cover $>4 \times 10^{4} \mathrm{~km}^{2}$ and sometimes $>9 \times 10^{4} \mathrm{~km}^{2}$ from infrared satellite data, between $0.4 \times 10^{12}$ and $1.0 \times 10^{12} \mathrm{gC}$ $\mathrm{yr}^{-1}\left(4 \times 10^{5}\right.$ and $1 \times 10^{6} \mathrm{t}$ of $\left.\mathrm{C} \mathrm{yr}^{-1}\right)$ may be delivered to sediments of the southeastern Caribbean Sea.

The final question is What is the source of the $\mathrm{CO}_{2}$ that provides the carbon that is deposited in sediments of the Cariaco Basin system? In open ocean surface water, carbon cycling tends to deplete near-surface $\mathrm{CO}_{2}$, resulting in a net flux from the atmosphere into the ocean. However, in a system like the Cariaco Basin the upwelling process brings water enriched in DIC and with a high fugacity of $\mathrm{CO}_{2}$ into the euphotic zone. Even though $\mathrm{CO}_{2}$ fugacity in surface waters decreased during the highly productive upwelling season, aquatic $\mathrm{CO}_{2}$ remained near or above the atmospheric partial pressure of $\sim 360 \mu$ atm essentially at all times. Thus, counterintuitively, the southeastern Caribbean is a source of $\mathrm{CO}_{2}$ on a year-round basis in spite of the substantial primary production occurring there. This is important since intensification of the "biological pump" is often considered to be a key mechanism for drawing down atmospheric $\mathrm{CO}_{2}$.

This poses an interesting question regarding the role of continental margins in the global carbon cycle. Viewed as a purely vertical system, the Cariaco upwelling system is a source of $\mathrm{CO}_{2}$ to the atmosphere on a year-round basis. In this respect the CARIACO basin, as an analog for continental margins, does not appear to provide a ready mechanism for sequestration of anthropogenic atmospheric $\mathrm{CO}_{2}$ in spite of the high primary productivity and organic carbon sedimentation rates seen there. However, the significance of the downward flux of particulate carbon at this continental margin lies in its role as a sink for $\mathrm{CO}_{2}$ captured within SUW as it is formed in the North Atlantic. Because SUW is advected into the Cariaco system, it is a source of new nutrients as well as of new $\mathrm{CO}_{2}$. Some of this carbon sinks when incorporated into the particulate flux, and some is vented to the atmosphere as $\mathrm{CO}_{2}$. The upwelling process along the southern Caribbean margin therefore represents a remote sink for $\mathrm{CO}_{2}$ previously sequestered from the surface within the North Atlantic gyre in the area of formation of the SUW. We may extend this analogy to other continental margins and view upwelling areas as both nutrient traps and areas of $\mathrm{CO}_{2}$ outgassing.

\section{Conclusions}

The CARIACO results show that primary productivity of this tropical ocean margin is extremely high, with the assimilation ratio at its temperature maximum all year round. Previous estimates of annual production for the Cariaco Basin were low by factors of 2-3 because of undersampling of the high production events driven by transient physical structures. Indeed, upwelling of SUW and ventilation of the Cariaco Basin lead to increased primary production in surface waters and to increased settling flux of particulate carbon. Surface $\mathrm{CO}_{2}$ fugacity is lower during the upwelling season relative to nonupwelling periods, reflecting the lower temperature, complete nutrient utilization, and upwelling of water that is nutrientenriched relative to carbon. This is further evidence that the Cariaco Basin serves as regional carbon sink for $\mathrm{CO}_{2}$ entrained at remote locations, such as in midlatitude gyres where the SUW is formed.

Estimates of rates of carbon remineralization in the water column of the Cariaco Basin from sediment traps suggest remi- 
neralization is comparable to that seen in the open ocean in spite of the suboxic-anoxic nature of much of the water column. Data from direct microbial measurements suggest that remineralization is largely localized in the surface mixed layer and near the suboxic-anoxic interface. These data have also shown that remineralization rates vary somewhat with season (and primary production rate). The export rates (normalized to total primary production) seem to vary little in the transition from upwelling to nonupwelling season. This is different from the Eppley and Peterson [1979] finding that the fraction of new to total production increases as total production for the deep ocean increases but is similar to what others have found more recently in assessing export production. An additional finding is that the oxic-anoxic boundary is a zone of both high microbial heterotrophic and autotrophic processes.

Results suggest that upwelling along the southeastern Caribbean Sea margin is not only responsive to seasonal trade wind intensification. It is possible that there is a more direct association with the meridional tilting of the thermocline in the Caribbean Sea, which reflects the remotely forced changes in geostrophic flow through the basin. Transient eddies in the Caribbean and fluctuations in the meridional component of the local wind are likely to play a role in ventilation events. This suggests that this site can be used to assess the impact of larger-scale phenomena, which then would also help to understand better the paleo-oceanographic record.

The CARIACO site is located above sediments that have been shown to retain a high-quality record of sediment deposition for at least the past 12,000 years [Hughen et al., 1996]. A recent study of these sediments [Haug et al., 1998] concluded that nitrogen fixation plays an important role in controlling the settling carbon flux in the modern Cariaco Basin and that this is a consequence of high denitrification rates. The CARIACO study found the oxic-anoxic interface at about $250 \mathrm{~m}$, and nitrate data show an indication of denitrification as shallow as about $130 \mathrm{~m}$ during July-November, the nonupwelling period. However, during upwelling the source of nutrients for surface production is water associated with the SUW, which has an elevated nitrate content. Therefore it is likely that mechanisms other than local nitrogen fixation may control the $\delta^{15} \mathrm{~N}$ signature detected by Haug et al. [1998] in the Cariaco Basin sediments.

The results suggest that the Cariaco Basin serves as a recorder of both ancient and modern changes occurring over regional and possibly basin scales. The question remains of how widely some of these findings can be extrapolated to other margins.

Acknowledgments. This work was supported by the National Science Foundation (NSF grants OCE-9216626, OCE-9729284, OCE9401537, OCE-9729697, OCE-9415790, and OCE-9711318), the National Aeronautics and Space Administration (NASA grants NAG56448 and NAS5-97128), and the Consejo Nacional de Investigaciones Cientificas y Tecnologicas (CONICIT, Venezuela, grant 96280221). We are indebted to the personnel of the Fundacion La Salle de Ciencias Naturales, Estacion de Investigaciones Marinas Isla Margarita (FLASA/EDIMAR) for its enthusiasm and professional support. In particular, we thank Pablo Mandazen (Hermano Gines, Director, FLASA) for his confidence in our activities and the crew of the $R / V$ Hermano Gines (FLASA) for its able support at sea. Jonnathan Garcia, Javier Gutierrez, Anadiuska Rondon (all at FLASA/EDIMAR), John Akl, and Ana Lucia Odriozola (at USF) provided essential field and laboratory support. Luis Troccoli, Wilfredo Patiño, Luis Sanchez, and William Senior, from the Universidad de Oriente, Cumana, Venezuela, provided nutrient data. Maria Iabichela, also from the Univer- sidad de Oriente, assisted in the bacterial productivity assays. The Biotechnology Laboratory of Empresas Polar in Caracas, Venezuela, has kindly allowed access to their scintillation counter for our primary productivity assessments. State University of New York Marine Sciences Research Center contribution number 1196.

\section{References}

Bacon, M. P., P. G. Brewer, D. W. Spencer, J. W. Murray, and J. Goddard, Lead-210, polonium-2210, manganese and iron in the Cariaco Trench, Deep Sea Res., Part A, 27, 119-135, 1980.

Ballester, A., and R. Margalef, Produccion primaria, Memoria, XXV, 209-221, 1965

Behrenfeld, M. J., and P. G. Falkowski, Photosynthetic rates derived from satellite-based chlorophyll concentration, Limnol. Oceanogr., 42, 1-20, 1997.

Berner, R. A., Comments on the role of marine sediment burial as a repository for anthropogenic $\mathrm{CO}_{2}$, Global Biogeochem. Cycles, 6 , 1-2, 1992.

Black, D. E., L. C. Peterson, J. T. Overpeck, A. Kaplan, M. N. Evans, and $M$. Kashgarian, Eight centuries of North Atlantic Ocean atmosphere variability, Science, 286, 1709-1713, 1999.

Breland, J. A. II, and R. H. Byrne, Spectrophotometric procedures for determination of sea water alkalinity using bromocresol green, Deep Sea Res., Part I, 40, 629-641, 1993.

Brown, O. B., J. W. Brown, and R. H. Evans, Calibration of advanced very high resolution radiometer infrared observations, $J$. Geophys. Res., 90, 11,667-11,678, 1985.

Byrne, R. H., and J. A. Breland, High precision multiwavelength $\mathrm{pH}$ determinations in sea water using cresol red, Deep Sea Res., Part $A$, 36, 803-810, 1989.

Carton, J. A., and Y. Chao, Caribbean Sea eddies inferred from TOPEX/Poseidon altimetry and a $1 / 6^{\circ}$ Atlantic Ocean model simulation, J. Geophys. Res., 104, 7743-7752, 1999.

Chavez, F. P., Forcing and biological impact of onset of the $1992 \mathrm{El}$ Niño in central California, Geophys. Res. Lett., 23, 265-268, 1996.

Clayton, T. D., and R. H. Byrne, Spectrophotometric seawater $\mathrm{pH}$ measurements: Total hydrogen ion concentration scale calibration of m-cresol purple and at-sea results, Deep Sea Res., Part I, 40, 2115-2129, 1993.

Curl, H., Primary production measurements in the north coastal waters of South America, Deep Sea Res. Oceanogr. Abstr., 7, 183-189, 1960.

DelValls, T. A., and A. G. Dickson, The $\mathrm{pH}$ of buffers based on 2-amino-2-hydroxymethyl-1,3-propanediol ('tris') in synthetic sea water, Deep Sea Res., Part I, 45, 1541-1554, 1998.

Deuser, W. G., Cariaco Trench: Oxidation of organic matter and residence time of anoxic water, Nature, 242, 601-603, 1973.

Deuser, W. G., F. E. Muller-Karger, R. H. Evans, O. B. Brown, W. E. Esaias, and G. C. Feldman, Surface-ocean color and deep-ocean carbon flux: How close a connection?, Deep Sea Res., Part A, 37, 1331-1343, 1990.

Eppley, R. W., Temperature and phytoplankton growth in the sea, Fish. Bull., 70, 1063-1085, 1972.

Eppley, R. W., and B. J. Peterson, Particulate organic matter flux and planktonic new production in the deep ocean, Nature, 282, 677-680, 1979.

Etcheber, H., S. Heussner, O. Weber, A. Dinet, X. Durrieu de Madron, A. Monaco, R. Buscail, and J. C. Miquel, Organic carbon fluxes and sediment biogeochemistry on the French Mediterranean and Atlantic margins, in Particle Flux in the Ocean, SCOPE, vol. 57, edited by V. Ittekkot et al., chap. 12, pp. 223-241, John Wiley, New York, 1996.

Falkowski, P., and D. A. Kiefer, Chlorophyll fluorescence in phytoplankton: Relationship to photosynthesis and biomass, J. Plankton Res., 7, 715-731, 1985.

Falkowski, P. G., R. T. Barber, and V. Smetacek, Biogeochemical controls and feedbacks on ocean primary production, Science, 281, 200-206, 1998.

Febres-Ortega, G., and L. E. Herrera, Interpretacion dinamica de algunas de las caracteristicas oceanograficas de la Fosa de Cariaco, Mar Caribe, Bol. Inst. Oceanogr. Univ. Oriente, 14, 3-29, 1975.

Field, C. B., M. J. Behrenfeld, J. T. Randerson, and P. Falkowski, Primary production of the biosphere: Integrating terrestrial and oceanic components, Science, 281, 237-240, 1998.

Froelich, P. N., D. K. Atwood, and G. S. Giese, The influence of Amazon River water on surface salinity and dissolved silicate concentration in the Caribbean Sea, Deep Sea Res., 25, 735-744, 1978. 
Hansell, D. A., and C. A. Carlson, Net community production of dissolved organic carbon, Global Biogeochem. Cycles, 12, 443-453, 1998.

Haug, G., T. Pedersen, D. Sigman, S. Calvert, B. Nielsen, and L. Peterson, Glacial/interglacial: Variations in production and nitrogen fixation in the Cariaco Basin during the last $580 \mathrm{kyr}$, Paleoceanography, 13, 427-432, 1998.

Henrichs, S. M., Early diagenesis of organic matter: The dynamics (rates) of cycling of organic compounds, in Organic Geochemistry: Principles and Applications, edited by M. H. Engel and S. A. Macko, pp. 101-114, Plenum, New York, 1993.

Herrera, L. E., and G. Febres-Ortega, Procesos de surgencia y de renovacion de Aguas en la Fosa de Cariaco, Mar Caribe, Bol. Inst. Oceanogr. Univ. Oriente, 14, 31-44, 1975.

Holmen, K. J., and C. G. Rooth, Ventilation of the Cariaco Trench, a case of multiple source competition?, Deep Sea Res., Part A, 37, 203-225, 1990.

Holm-Hansen, O., C. J. Lorenzen, R. W. Holmes, and J. D. H. Strickland, Fluorometric determination of chlorophyll, J. Cons. Int. Explor. Mer, 30, 3-15, 1965.

Honjo, S., and K. Doherty, Large aperture time series oceanic sediment traps: Design objectives, construction and application, Deep Sea Res., Part A, 35, 133-149, 1988.

Honjo, S., D. W. Spencer, and J. W. Farrington, Deep advective transport of lithogenic particles in Panama Basin, Science, 216, 516$518,1982$.

Hughen, K., J. Overpeck, L. Peterson, and S. Trumbore, Rapid climate changes in the tropical Atlantic region during the last glaciation, Nature, 380, 51-54, 1996.

Hughen, K. A., J. T. Overpeck, S. J. Lehman, M. Kashgarian, J. Southon, L. C. Peterson, R. Alley, and D. M. Sigman, Deglacial changes in ocean circulation from an extended radiocarbon calibration, $\mathrm{Na}$ ture, 391, 65-68, 1998.

Jahnke, R. A., The global ocean flux of particulate organic carbon: Areal distribution and magnitude, Global Brogeochem. Cycles, 10, 71-88, 1996.

Karl, D., J. Christian, J. Dore, D. Hebel, R. Letelier, L. Tupas, and C. Winn, Seasonal and interannual variability in primary production and particle flux at Station ALOHA, Deep Sea Res., Part II, 43, 539-568, 1996.

Kinder, T. H., G. W. Heburn, and A. W. Green, Some aspects of Caribbean circulation, Mar. Geol., 68, 25-52, 1985.

Kirchman, D. L., Leucine incorporation as a measure of biomass production by heterotrophic bacteria, in Handbook of Methods in Aquatic Microbial Ecology, edited by P. F. Kemp et al., pp. 509-512, Lewis, Boca Raton, Fla., 1993.

Kishino, M., M. Takahashi, N. Okami, and S. Ichimura, Estimation of the spectral absorption coefficients of phytoplankton in the sea, Bull. Mar. Sci., 37, 634-642, 1985.

Koblentz-Mishke, O. J., V. V. Volkovinsky, and J. G. Kabanova, Plankton primary production of the world ocean, in Scientific Exploration of the Southern Pacific, edited by W. S. Wooster, pp. 183-193, Natl. Acad. of Sci., Washington, D. C., 1970.

Lee, C., Controls on organic carbon preservation: The use of stratified water bodies to compare intrinsic rates of decomposition in oxic and anoxic systems, Geochim. Cosmochim. Acta, 56, 3323-3335, 1992.

Lidz, L., W. B. Charm, M. M. Ball, and S. Valdes, Marine basins off the coast of Venezuela, Bull. Mar. Sci., 19, 1-17, 1969.

Margalef, R., Composicion y distribucion del fitoplancton, Memoria, $X X V, 141-205,1965$.

Margalef, R., F. Cervigon, and G. T. Yepez, Exploracion preliminar de las caracteristicas hidrograficas y de la distribucion del fitoplancton en el area de la Isla Margarita (Venezuela), Memorias, $X X$, 211-221, 1960.

McClain, E. P., W. G. Pichel, C. C. Walton, Z. Ahmad, and J. Sutton, Multi-channel improvements to satellite-derived global sea-surface temperatures, Adv. Space Res., 2(6), 43-47, 1983.

Merhbach, C., C. H. Culberson, J. E. Hawley, and R. M. Pytkowicz, Measurement of the apparent dissociation constants of carbonic acid in seawater at atmospheric pressure, Limnol. Oceanogr., 18, 897-907, 1973.

Millero, F. J., Thermodynamics of the carbon dioxide system in the oceans, Geochum. Cosmochim. Acta, 59, 661-677, 1995.

Minnett, P. J., Consequences of sea surface temperature variability on the validation and applications of satellite measurements, J. Geophys. Res., 96, 18,475-18,489, 1991.
Morris, I., A. E. Smith, and H. E. Glover, Products of photosynthesis in phytoplankton off the Orinoco River and in the Caribbean Sea, Limnol. Oceanogr., 26, 1034-1044, 1981.

Morrison, J. M., and W. D. Nowlin Jr., General distributions of water masses within the eastern Caribbean Sea during winter of 1972 and fall of 1983, J. Geophys. Res., 87, 4207-4229, 1982.

Morrison, J. M., and O. P. Smith, Geostrophic transport variability along the aves ridge in the eastern Caribbean Sea during 1985-1986, J. Geophys. Res., 95, 699-710, 1990.

Muller-Karger, F. E., and R. Aparicio, Mesoscale processes affecting phytoplankton abundance in the southern Caribbean Sea, Cont. Shelf Res., 14, 199-221, 1994.

Muller-Karger, F. E., C. R. McClain, T. R. Fisher, W. E. Esaias, and R. Varela, Pigment distribution in the Caribbean Sea: Observations from Space, Prog. Oceanogr., 23, 23-69, 1989.

Muller-Karger, F. E., P. L. Richardson, and D. McGillicuddy, On the offshore dispersal of the Amazon's plume in the North Atlantic, Deep Sea Res., Part I, 42, 2127-2137, 1995.

Murphy, S. J., H. E. Hurlburt, and J. J. O'Brien, The connectivity of eddy variability in the Caribbean Sea, the Gulf of Mexico, and Atlantic Ocean, J. Geophys. Res., 104, 1431-1453, 1999.

Olivieri, R. A., and F. P. Chavez, A model of plankton dynamics for the coastal upwelling system of Monterey Bay, California, Deep Sea Res., Part II, 47, 1077-1106, 2000.

Pace, M., G. Knauer, D. Karl, and J. Martin, Primary production, new production and vertical flux in the eastern Pacific Ocean, Nature, 325, 803-804, 1987.

Peterson, L. C., J. T. Overpeck, N. G. Kipp, and J. Imbrie, A highresolution late Quaternary upwelling record from the anoxic Cariaco Basin, Venezuela, Paleoceanography, 6, 99-119, 1991.

Pilskaln, C. H., J. B. Paduan, F. P. Chavez, R. Y. Anderson, and W. M. Berelson. Carbon export and regeneration in the coastal upwelling system of Monterey Bay, central California, J. Mar. Res., 54, 1149$1178,1996$.

Redfield, A. C., B. H. Ketchum, and F. A. Richards, The influence of organisms in the composition of sea water, in The Sea, edited by M. N. Hill, chap. 2, pp. 26-77, Interscience, New York, 1963.

Richards, F. A., Some chemical and hydrographic observations along the north coast of South America, I, Cabo Tres Puntas to Curacao, including the Cariaco Trench and the Gulf of Cariaco, Deep Sea Res., 7, 163-182, 1960.

Richards, F. A., The Cariaco Basin (Trench), Oceanogr. Mar. Biol. Annu. Rev., 13, 11-67, 1975.

Richards, F. A., and R. F. Vacearo, The Cariaco Trench, an anaerobic basin in the Caribbean Sea, Deep Sea Res., 3, 214-228, 1956.

Robert-Baldo, G., M. J. Morris, and R. H. Byrne, Spectrophotometric determination of seawater $\mathrm{pH}$ using phenol red, Anal. Chem., 57, 2564-2567, 1985.

Scranton, M. I., Temporal variations in the methane content of the Cariaco Trench, Deep Sea Res., 35, 1511-1523, 1988.

Scranton, M. I., F. L. Sayles, M. P. Bacon, and P. G. Brewer, Temporal changes in the hydrography and chemistry of the Cariaco Trench, Deep Sea Res., Part A, 34, 945-963, 1987.

Scranton, M. I., Y. Astor, R. Bohrer, T.-Y. Ho, and F. E. MullerKarger, The effect of recent subsurface water mass intrusions on the geochemistry of the Cariaco Basin, Deep Sea Res., in press, 2001.

Spencer, D. W., Aluminum concentrations and fluxes in the ocean, in Global Ocean Flux Study: Proceedings of a Workshop, pp. 206-220, Natl. Acad., Washington, D. C., 1984.

Steeman Nielsen, E., The use of radioactive carbon $\left({ }^{14} \mathrm{C}\right)$ for measuring organic production in the sea, J. Cons. Int. Explor. Mer, 18, $117-140,1952$.

Strong, A. E., and E. P. McClain, Improved ocean surface temperatures from space: Comparisons with drifting buoys, Bull. Am. Meteorol. Soc., 65, 138-142, 1984.

Thunell, R., Seasonal and annual variability in particle fluxes in the Gulf of California: A response to climate forcing, Deep Sea Res., 45, 2059-2083, 1998a.

Thunell, R., Particle fluxes in a coastal upwelling zone: Sediment trap results from Santa Barbara Basin, California, Deep Sea Res., 45, 1863-1884, 1998b.

Thunell, R., E. Tappa, R. Varela, M. Llano, Y. Astor, F. MullerKarger, and R. Bohrer, Increased marine sediment suspension and fluxes following an earthquake, Nature, 398, 233-236, 1999.

Thunell, R., R. Varela, M. Llano, J. Collister, F. Muller-Karger, and R. Bohrer, Organic carbon flux in an anoxic water column: Sediment 
trap results from the Cariaco Basin, Limnol. Oceanogr., 45, 300-308, 2000.

United Nations Educational, Scientific, and Cultural Organization (UNESCO), Protocols for the Joint Global Ocean Flux Study (JGOFS) core measurements, in IOC Manuals and Guides, vol. 29, pp. 128-140, Paris, 1994.

Volk, T., and $\mathrm{Z}$. Liu, Controls of $\mathrm{CO}_{2}$ sources and sinks in the earth scale surface ocean: Temperature and nutrients, Global Biogeochem. Cycles, 2, 73-89, 1988.

Walsh, J. J., On the Nature of Continental Shelves, 520 pp., Academic, San Diego, Calif., 1988.

Walsh, J. J., Importance of continental margins in the marine biogeochemical cycling of carbon and nitrogen, Nature, 350, 53-55, 1991.

Walsh, J. J., K. L. Carder, and F. M. Muller-Karger, Meridional fluxes of dissolved organic matter in the North Atlantic Ocean, J. Geophys. Res., 97, 15,625-15,637, 1992.

Walsh, J. J., et al., Simulation of carbon/nitrogen cycling during spring upwelling in the Cariaco Basin, J. Geophys. Res., 104, 7807-7825, 1999.

Walton, C. C., Nonlinear multichannel algorithms for estimating sea surface temperature with AVHRR satellite data, J. Appl. Meteorol., 27, 115-124, 1988.

Wright, R. T., and J. E. Hobbie, Use of glucose and acetate by bacteria and algae in aquatic ecosystems, Ecology, 47, 447-463, 1966.

Y. Astor, J. Capelo, and R. Varela, Fundacion La Salle de Ciencias Naturales, Estacion de Investigaciones Marinas de Margarita, Apartado 144 Porlamar, Isla de Margarita, Venezuela.

R. Bohrer, F. Muller-Karger, and J. J. Walsh, College of Marine Science, University of South Florida, St. Petersburg, FL 33701. (carib@carbon.marine.usf.edu)

T.-Y. Ho, M. Scranton, and G. Taylor, Marine Sciences Research Center, SUNY, Stony Brook, NY 11794.

E. Tappa and R. Thunell, Department of Geological Sciences, University of South Carolina, Columbia, SC 29208.

(Received May 7, 1999; revised July 19, 2000; accepted July 27, 2000.) 